\title{
STAKEHOLDER-CENTERED ONTOLOGIES FOR EDUCATIONAL DESIGNS
}

\author{
Ch. Stary ${ }^{1, \mathrm{a}}$, M. Neubauer ${ }^{1, \mathrm{~b}}$, St. Oppl ${ }^{1, \mathrm{c}}$, G. Weichhart ${ }^{2}$ \\ ${ }^{I}$ Department of Business Information Systems - Communications Engineering, Johannes Kepler University Linz, \\ Austria,www.ce.jku.at, ${ }^{a}$ Christian.Stary@jku.at, ${ }^{b}$ Matthias.Neubauer@jku.at, ${ }^{c}$ Stefan.Oppl@jku.at \\ ${ }^{2}$ Profactor GmbH, Steyr, Austria,www.profactor.at, Georg.Weichhart@profactor.at
}

\begin{abstract}
E-Learning and Knowledge Management environments are increasingly becoming highly interactive and content-rich. They encapsulate social, cognitive, and technological aspects. Concept maps are effective means to generate and organize multiple grounded knowledge for sharing content and trigger behavior along learning and development processes. Since the basic concept map structure and procedure can easily be explained, the various stakeholders engaged in learning processes and knowledge management activities can benefit from these capabilities. Concept maps allow encoding not only relevant information but also elaborating different perspectives on information elements. In this way, meaningful content and features for interaction can effectively be conveyed. We demonstrate the non-intrusive and non-disruptive use of concept maps for user- and usage-centered design of learning environments. The approach spans from articulating educational designs and tagging didactic content to purposeful navigation and traceable design spaces. We use metadata to encode educational intention for learning support. They also allow using content elements in different educational contexts. Their handling can be aligned with existing features of learning support systems including social media. By understanding such application development as a learning process itself, concept mapping enforces systemic understanding and thus, accelerates further developments in context-sensitive design, as our findings from the field reveal.
\end{abstract}

Key words: ontology engineering, concept map, eLearning, knowledge generation, knowledge representation, topic map, knowledge sharing, progressive education, self-directed learning, user-centered design, design space, distributed systems.

\section{Introduction}

Michael Feldstein, in his recent reflection on MOOC (massive open online course) developments, rephrases the still valid quest for goal setting in technology-supported education and learning [1]. With respect to the effectiveness of pedagogical models, one of the commonly agreed cornerstones of e-learning developments, he argues for different design thinking, quoting George Siemens: "The connectivist view that learning is a network creation process significantly impacts how we design and develop learning within corporations and educational institutions. When the act of learning is seen as a function under the control of the learner, designers need to shift the focus to fostering the ideal ecology to permit learning to occur. By recognizing learning as a messy, nebulous, informal, chaotic process, we need to rethink how we design our instruction. Instruction is currently largely housed in courses and other artificial constructs of information organization and presentation. Leaving this theory behind and moving toward a networked model requires that we place less emphasis on our tasks of presenting information, and more emphasis on building the learner's ability to navigate the information (i.e. connectivism)" [2].

Such "educational goals ... are framed in direct contrast to the traditional methods and goals of schooling" [1, p.4]. They need to take into account cultural factors beyond cognition and technology, and are likely to affect the role understanding of teachers and learners, such as induced by Ri- 
chard D. Garrison's (unifying) transactional perspective: "While knowledge is a social artefact, in an educational context, it is the individual learner who must grasp its meaning or offer an improved understanding. The purposeful process of facilitating an outcome that is both socially and personally worthwhile goes to the heart of the teaching and learning transaction. This transaction is common to all educational experiences, including e-learning.

Thus, an educational experience has a dual purpose. The first is to construct meaning (reconstruction of experience) from a personal perspective. The second is to refine and confirm this understanding collaboratively within a community of learners. At first glance, this dual purpose would seem to reflect, respectively, the distinct perspectives of the teacher and student. However, closer consideration of the transaction reveals the inseparability of the teaching and learning roles and the importance of viewing the educational process as a unified transaction. We are simply viewing the same process from two different perspectives. These two perspectives raise fundamental questions concerning issues of responsibility for learning and control of the process." [3, p. 62].

In e-learning designs reflection of educators and increased learner control has been part of shifting from teacher-controlled to self-directed learning processes (cf. [4]). Since it affects educational settings, didactic elements increasingly gets questioned by principles of mathetics (cf. $[5,6])$. When educators share the responsibility of the learning process with learners the preparation of the environment becomes essential for self-managed learning (cf. [7]). It is for e-learning of particular importance to get learners interested in being exposed to various learning modes (termed polyvalent by Leclercq [8]) exploiting a variety of methods and resources on provided content elements [9]. As such, e-learning designs require not only transparent acquiring and representing how content is prepared for learning, but also revising interaction facilities and information structures, e.g., recognizing the social character of transfer processes (cf. [10]).

Concept maps [11] are widely used as effective and valid means to elicit, represent, and share knowledge [12]. Albeit being traditionally utilized in educational settings [13-16], they have been introduced to organizational learning (cf. [17]), as they allow:

- making "thinking visible" in a socially accepted way [18]:

- embodying cognitive and social learning experience (cf. [19-20]).

Their fundamental structure and handling is kept simple and can easily be conveyed to different stakeholders. As such, they qualify for engaging the various stakeholders in learning processes and knowledge management activities, including experts (cf. [21]). The ease of use while ensuring a high degree of expressiveness due to their diagrammatic nature lays ground for user-/usage-centered design. The various stakeholders, in particular curriculum designers, educational content providers, authors, tutors, facilitators, and learners, need to interact within and across their peer group when aiming to put to practice the interactionist and connectivist stance addressed above. A coherent use of concept maps should bring e-learning developments closer to achieve Dewey's objective that finally, there can be no difference between educator and learner understanding, in particular, in democratic educational institutions [22].

In the course of learning and interaction the complex cognitive and social fabric develops dynamically, requiring stakeholders one hand to stay tuned to their role and its adjunct perspective(s), e.g., educators being domain expert and knowledge transfer designers, while on the other hand meeting contextual objectives at the same time, e.g., formal (institutional) qualification requirements and sense-making skill development for individual learners. To that respect, concept maps allow not only encoding different types of relevant information but also elaborating different perspectives on information elements [23]. By exchanging perspectives (cf. [24]) they allow stakeholders reflection [25], concerning the meaning of conveyed content and features for interaction in the case of e-learning developments (cf. [26]). 
The successful use of concept maps as tools for orientation, e.g., navigation in e-learning systems [27] in addition to content organization recommends their use when increasingly focusing on learner-centered designs besides presenting information (in the sense of [2]). Since concept maps allow for both, non-intrusive and non-disruptive user- and usage-centered design of learning environments should become possible.

Finally, the more self-organized the process of (re-)constructing knowledge can be organized the better problem-solving capabilities can be developed by learners [28]. Although from these empirical findings it can be concluded that integrating concept mapping into e-learning environments helps learners acquiring knowledge in a more effective way, a recent study reveals "it remains an open issue to find a suitable way of integrating concept maps into the learning process without introducing too much extra cognitive load" [28, p.77]. The connectivist view on learning [2] together with intertwining roles according to the interactionist approach as proposed by Garrison [3] could help to minimize cognitive load along learning processes.

Consequently, we propose to start using concept maps for eliciting mental models of educators (instructors, content providers etc.), including their domain and didactic understanding for a certain education task (cf. [29]), e.g., in terms of subject-specific learning paths. Subsequently, we offer learners to use representations of such kind as a means of orientation for navigation and individual learning path development (as part of content individualization). Implementing this concept should increase problem-solving capacity without burdening learning with existing domain and educational structures.

We introduce informed learning design along the following structure:

(i) Articulation support for intentional education (section 1)

(ii) Semantic navigation (section 2)

(iii) User-/Usage-centered design spaces (section 3)

Articulating educational design and using it for navigation lay ground for structuring design spaces (iii), as they link features of learning environments to domain structures and didactic models. They contain all required information for contextual design due to their systemic representation, enabled by concept maps. All conceptual findings have been tested in the field allowing to present concrete data and to instantiate methodological or technological concepts in each section. All sample cases refer to learner-centered didactics and/or the same application domain, namely Business Process Management (BPM). Both have been selected mainly for the following reasons:

- The authors are familiar to them, due to their personal background, research and development activities (cf. [7, 30, 31]);

- BPM is applied in practice across disciplines, in particular economics, organization, and information and communication technology (cf. [32])

- Coherent design in higher education, as, e.g. proposed by Kinchin [33] requires re-thinking learning in terms of processes - Business Process Management captures these essentials from an organizational and technology perspective.

We conclude the paper summarizing our objectives and achievements, in particular referring to contextualize concept mapping along the various phases of coherent e-learning development. We also refer to future work aligning intelligent content with social media management.

\section{Articulation Support of Intentional Education}

In this section concept mapping for eliciting educator knowledge is discussed. Being part of various acquisition approaches when designing learning environments concept mapping allows identifying several categories of relevant knowledge (cf. [34,35]):

- Domain structures; 
- Didactic patterns, including envisioned learning paths;

- Context of learning processes, such as situations of use.

Knowledge articulation is primarily a (meta-)cognitive effort to reflect on inputs to actions, e.g., educational resources, and causal links between actions and outcomes, e.g., triggering learning activities through engaging resources (cf. [36] referring to explicit articulation work). Concept maps, in particular when scaffolding (meta-)cognitive processes as hierarchy, cluster, or chain (cf. [37]), codify knowledge- a necessary precondition to enable others accessing und using externalized or generated knowledge [38]. Such documentations serve well as focal point for further processing, e.g., curriculum design [39], however, requiring to justify elicited knowledge (cf. [40]).

In the following, we structure the variety of opportunities to apply concept mapping when educational knowledge is generated. Although each application follows the basic idea, namely identifying and documenting concepts or nodes in their mutual context provided a topic or question $[11,14]$, the setting can be designed differently for effective utilization. We start with the open format given a certain topic, such as the design of a course (section 1.1). Such a scenario fits well for educators starting to reflect on their experiences and skills from a perspective of their choice, e.g., domain, institutional or didactic perspective (cf. [29]). It also meets the objective when 'an empty sheet' approach is required to open up for novel ideas. As [41] revealed generative concept maps could outperform prefabricated ones.

We proceed with elicitation procedures via structured interviews that turned out to set the stage for designing e-learning application in a comprehensive while focused way (section 1.2). It fits well to concept mapping, as concept maps facilitate analyzing existing learning resources, such as textbooks, in a structured way. Explicit content structures, finally, allow designing learning support systems including the didactic arrangement of content and its context, such as social interaction features (section 1.3).

\section{1 "Open" or Non-directed Elicitation and Reflection}

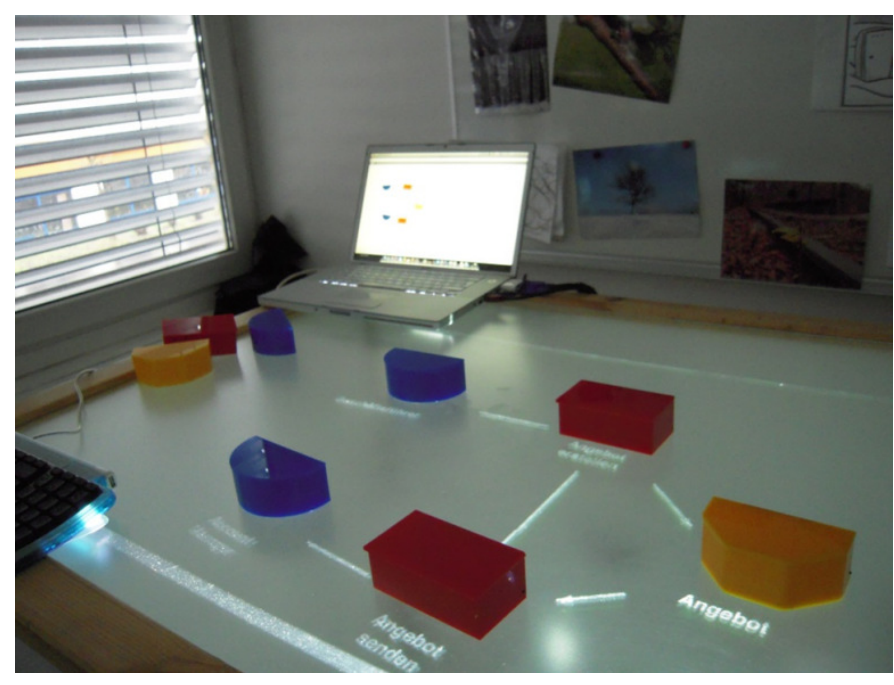

Figure 1- Tabletop concept mapping

This type of concept mapping starts with an objective, the participants need to agree upon. It may concern either an individual topic or a group task. Typically, the trigger to elicit and document educational knowledge and resources for educational design is the (re-)development of a course, or the occurrence of an educational challenge. The involved stakeholders start constructing a concept map by identifying nodes (concepts, meaningful items) and relationships on a virtual or paper surface, articulating their experiential knowledge. A variety of media for interaction can be provided, in particular paper, GUI-based applications, such as the Cmap tools [11, 42], and tabletop approaches, such as Comprehand [43, 44] see Figure 1.

Interactive table-top mapping in that context targets at tangible information spaces. Correspondingly, concepts/nodes as physical representations can be put on a tabletop surface, and linked by pushing two nodes against each other. Nodes and links may be provided with text that is then displayed on the table top. 3D-elements also allow 3D-nodes to be opened, in order to put in other ar- 
tefacts. Such artefacts may either be other maps, links to digital resources, e.g., web sites, or resources (files). Figure 2 shows the set of tabletop elements and the toolset for:

- Selecting elements (node or link) of a tabletop map going to be manipulated;

- Marking a link as directed relationship, e.g., indicating a procedure (chain);

- Removing a link or text label of a node or link (eraser tool);

- Storing the current state of the map as a snapshot in a repository for later use (snapshot tool);

- Step back in time showing previous snapshots (history tool).

Typically the semantics of a representation evolves in the course of identifying/putting nodes on the tabletop and creating links. As more than one person may be part of a mapping session, essential nodes and relations can be shared and stored as meaningful information for groups, including the generation of variants with respect to a certain issue (cf. [45]). Typical variants of course designs are subject-specific lectures for different curricula, e.g., computer science and business information systems, and thus educators with different intentions and learners with heterogeneous backgrounds.

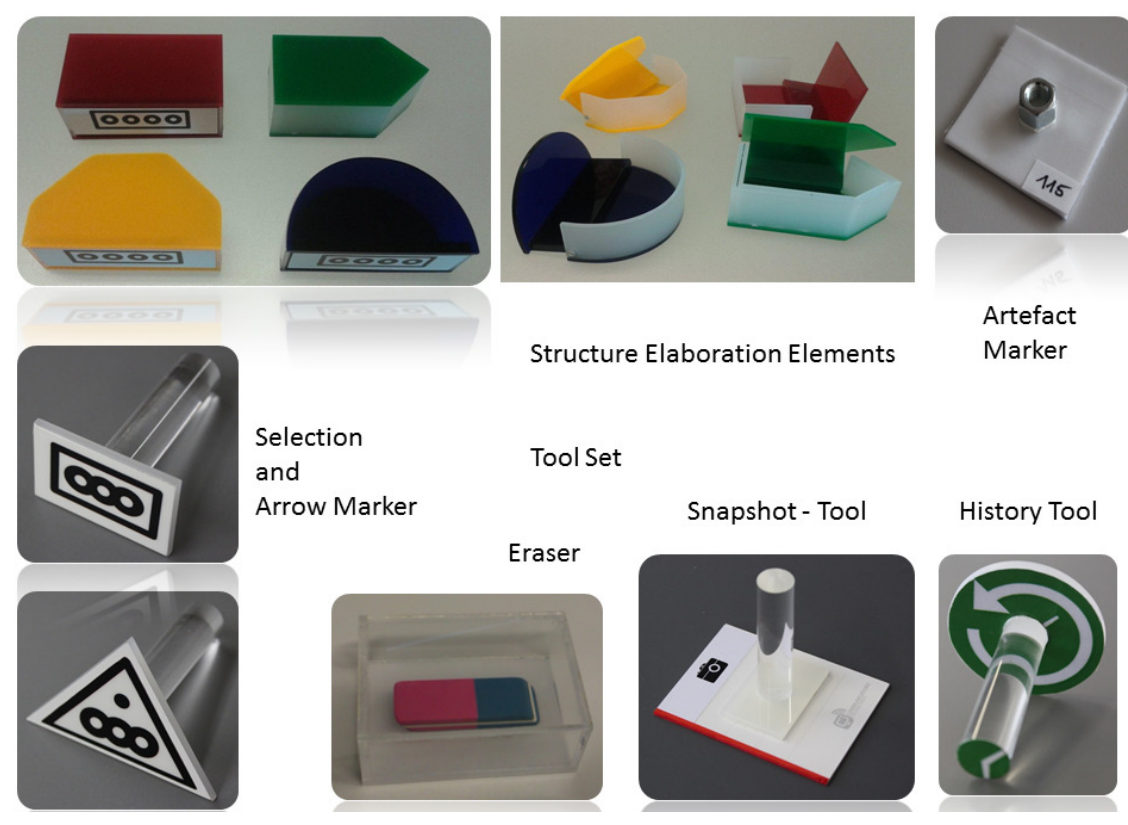

Figure 2 - Elements and Tools for Tabletop Concept Mapping

Due to the codes on the bottom of each 3D element, each element can be used according to a certain category of information (meaning), e.g., red elements represent text books, blue ones comments of learners. It is depending on the conventions evolving during knowledge generation whether the 3D-elements belong to certain categories of information (cf. [46]). Typically the semantics of a representation evolves in the course of identifying/putting nodes on the tabletop and creating links. As more than one person might be part of a mapping session, essential nodes and relations may be shared and stored as meaningful information for groups, including the generation of variants with respect to a certain issue (cf. [45]). Typical variants of course designs are subject-specific lectures for different curricula, e.g., computer science and information systems, and thus learners with different backgrounds.

The example given in Figure 3 stems from the preparation phase of the International Summer School on Subject-Driven Role-Guided Externalization of Organizational Models (Erasmus Intensive Programme sponsored by the Lifelong Learning Programme of the European Commission www.surgeom.eu). The figure shows some educational design principles for an introductory lecture on Business Process Management (BPM). Since the summer school is intended for students from different European countries and curricula (economics, organizational studies, computer science, 
business computing, information systems), the crucial task is to align their understanding with respect to major concepts of the field, and their nature.

The tabletop map reveals on the left side a chain (sequence) of two learning steps involving different learner groups. In a first step Learner Group 1 (upper left part of the figure) receives a bundle of information on BPM, composed of modeling foundations and the language standard on the Business Process Modeling Notation (BPMN) 2.0 (upper right part). Learner Group 1 is asked to annotate the BPM life cycle that can be found in "Modeling foundations" with examples according to their own experiences and background (cf. [47]). These annotations together with the other resources are passed on to Learner Group 2 to accomplish a practical BPM modeling task, namely Process Analysis for a service industry. The container function of the tabletop system (Map Artefact in Figure 2) has been used to put the map denoted by the rectangle into the red tabletop element (by using the Artefact Marker for a Snaphot) shown at the lower part (Input to Group 2 - Practical Assignment).

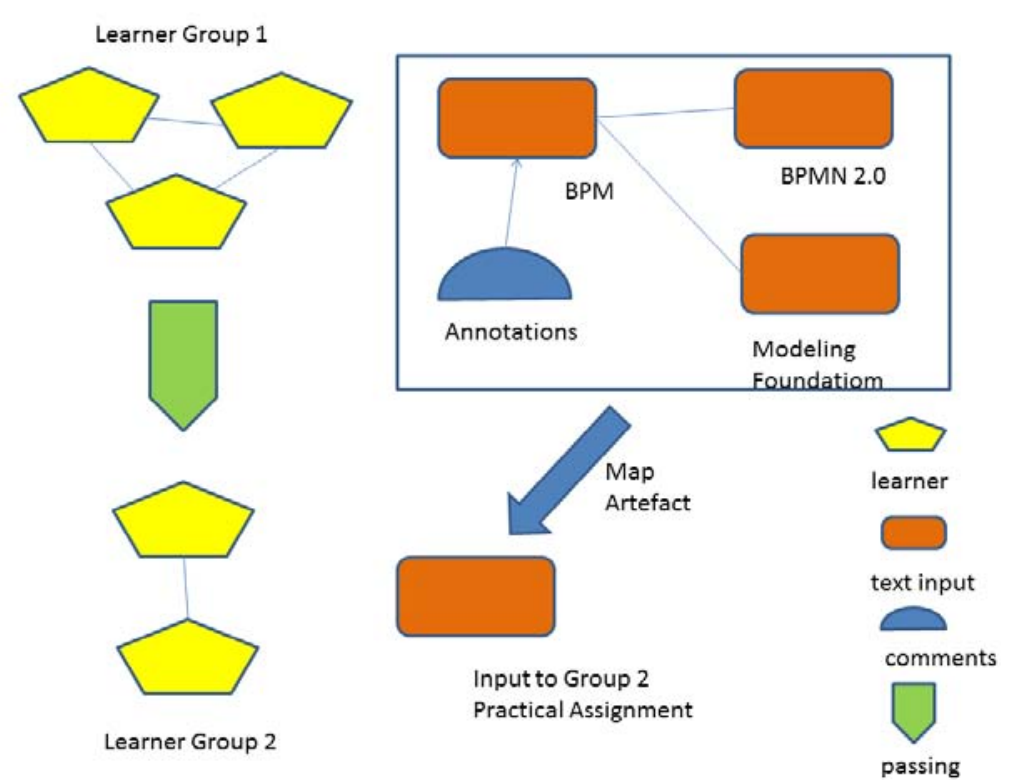

Figure 3 - Utilizing the benefits of tabletop concept mapping for articulating educational design - sample representations
In contrast to paper-based concept mapping the process of mapping may be recorded according to the needs of the users. Hence, the process of elaborating a structure may be traced and variants may be developed starting from any recorded state. In the presented system, due to the import into a GUI-based editor each map/snaphot may be processed further and be manipulated. For the tabletop system an export to the Cmap tool format ([42], cmap.ihmc.us) has been implemented, in order to allow processing the maps with a widely used GUI tool set. For procedural chains, such as shown on the left side in Figure 3 an export has been developed to a business process suite in the course of the European IANES project (www.ianes.eu).

\subsection{Setting up Didactic Requirements}

Benefits for education design can be created from reflecting and exploring didactic approaches using concept mapping. In this section, we exemplify such an endeavor for progressive education, a learner-centered approach oriented towards self-organization and constructivism (cf. [7, 31, 48-50]). Such comparative analyses for educational design follow a 4-step procedure:

1) Specifying the universe of discourse, such as identifying didactic approaches relevant for progressive education;

2) Detailing each constituent, collecting and structuring according to the information available, e.g., procedures, assumptions, empirical findings;

3) Cross-checking according to capabilities, e.g., degree of self-organization, effort of preparation;

4) Consolidating for further action, in particular requirements for e-learning. 
Figure 4 exemplifies step 1 for progressive education, naming all analyzed educationists, and thus, scoping the universe of analysis. Color codes are introduced facilitating traceability when cross-checking findings.

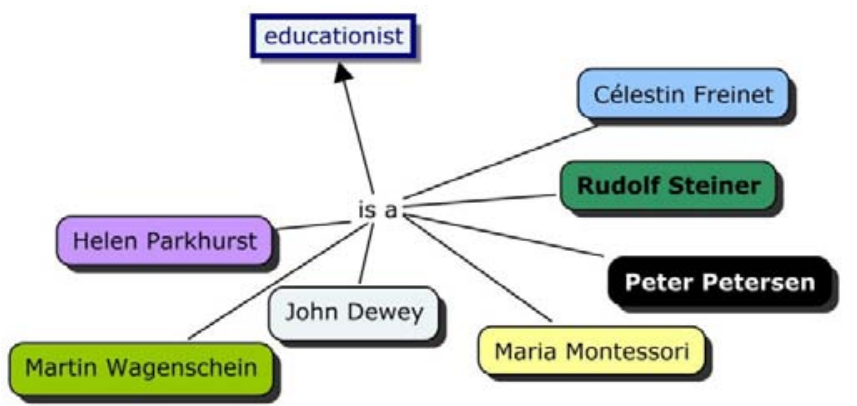

Figure 4 - Approaches to progressive education [50]

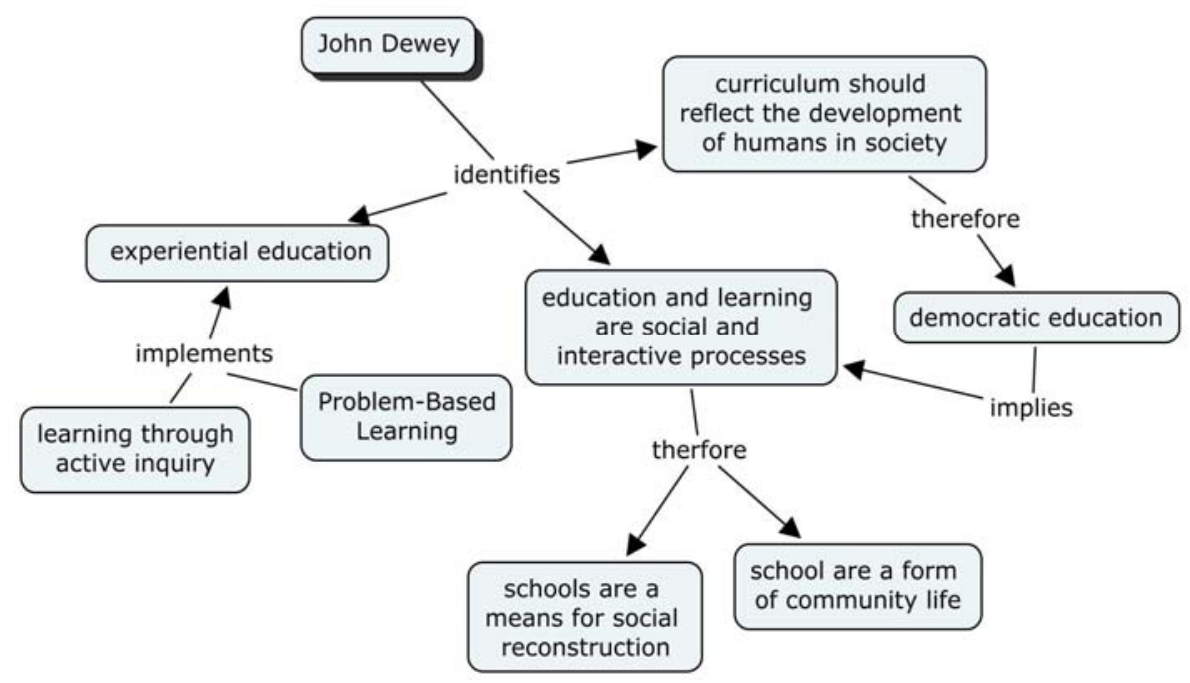

Figure 5 - John Dewey’s approach [51]

In step 2 each approach is detailed according to the source of information, in the sample case documented findings. John Dewey [51] (Figure 5) puts emphasis on educating children using democratic principles, and educating them to acquire experimental, self-organized learning capabilities allowing them to contribute actively to societal developments. Helen Parkhurst [52] (Figure 6) appreciated Montessori and Dewey. She developed the role of the teacher further, namely towards guiding learners rather than controlling them. The developed pedagogy is centered on two instruments, which allow the provision of guidance and progress monitoring. Assignments provide scaffolds instead of details how to solve a task. The progress of the students along these scaffolds is monitored using process graphs. Learning incorporates group work and cooperation.

In step 3 cross-check according to educational tasks are performed. Hereby, parts of the above concept maps on the individual pedagogical approaches are put into a single map, thus, providing an aggregated view on progressive education. In order to be able to identify the source of information of each concepts and link, they are coloured differently, as indicated in Figure 7. Concepts that are represented by a rectangular shape represent the core concept of the particular map.

The following map shows learning principles facilitating learner-centered capacity building. The analyzed approaches require learners to take care about the freedom to select or develop their individual problem solving capability in a self-responsible manner. The requested actively 
exploring of problems promote analytical thinking, creativity, practical abilities, and social capabilities for problem solving, since learning should also take place in groups.

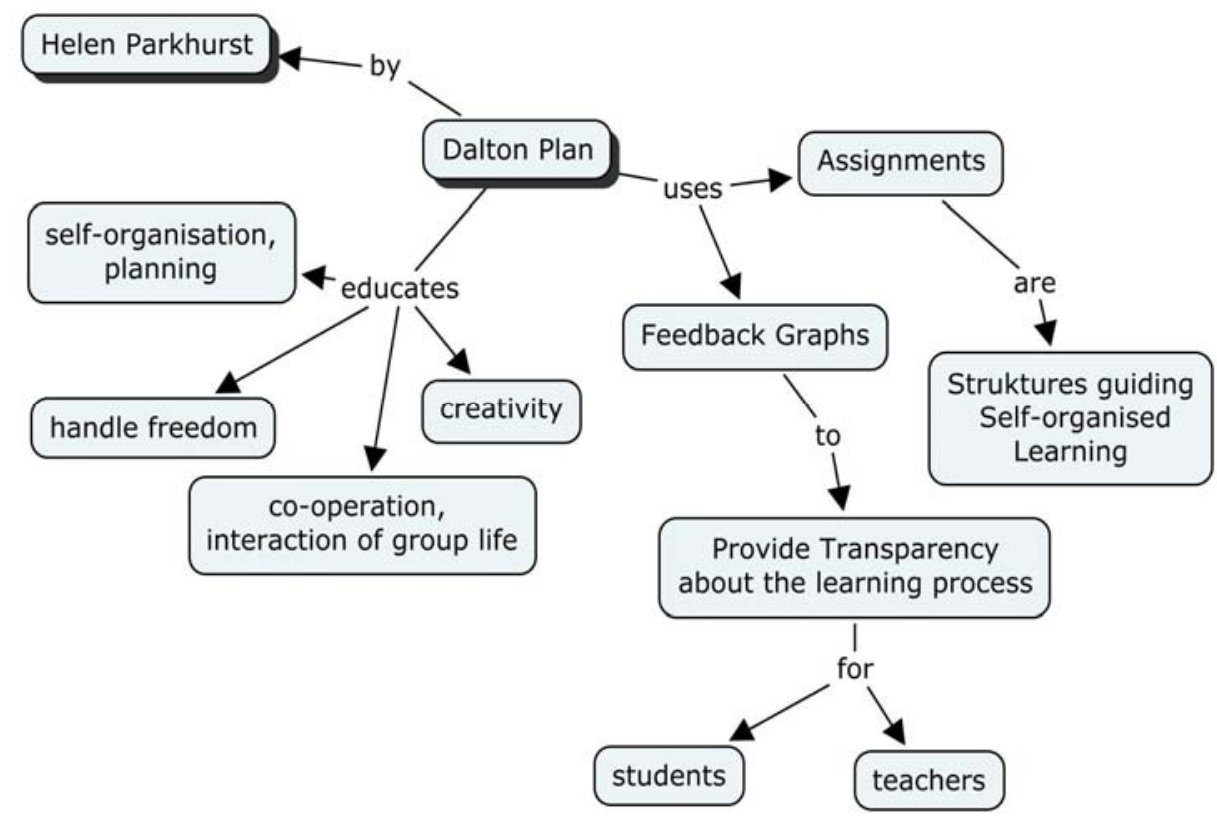

Figure 6 - Helen Parkhurst's approach [52]

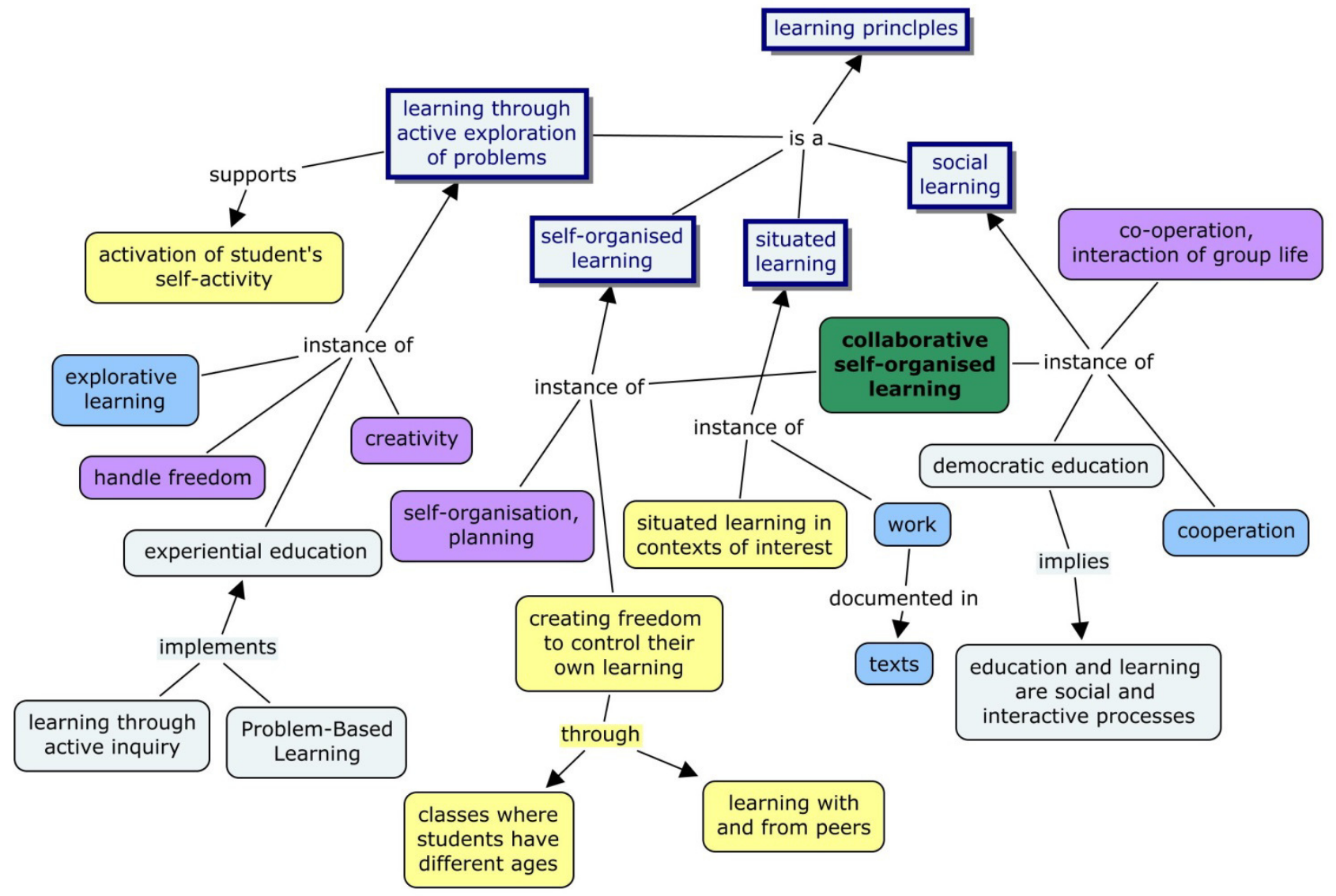

Figure 7 - Learning Principles 
Finally, in step 5 requirements for educational design in e-learning environments may be derived from the map in Figure 7. The concept map in Figure 8 conceptualizes a learning environment providing learning facilities according to the above mentioned principles, by showing enablers to achieve major objectives of progressive education.

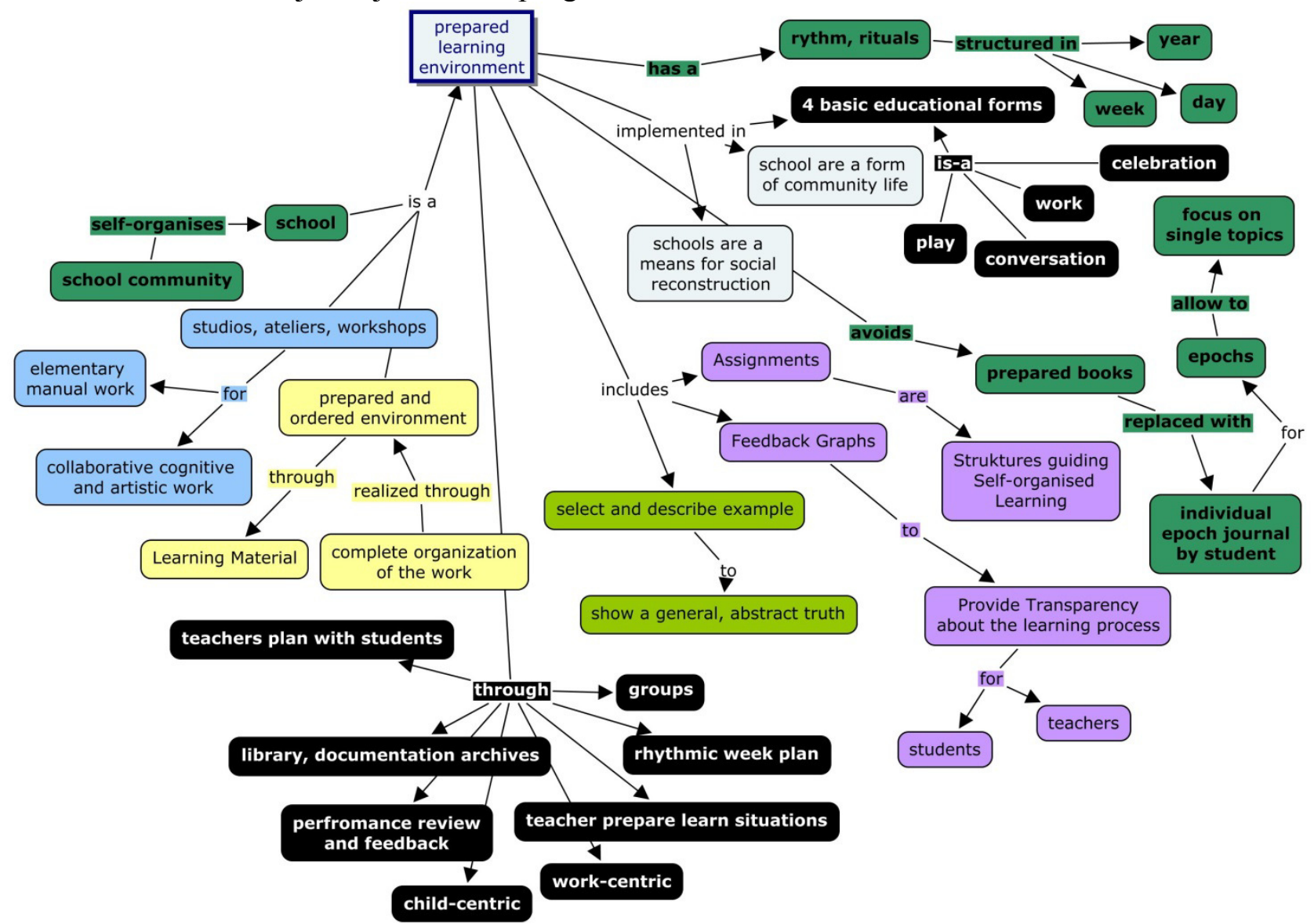

Figure 8 - Progressive learning environment requirements [50]

\subsection{Developing e-Learning Baselines (Course and Content Models)}

Although [53] could not demonstrate essential benefits for generating knowledge incorporating concept maps into interviewing, their work laid ground to structure narratives according to concepts, and thus apply concept mapping in the context of collecting educators' experiences for further engineering (cf. [54]). The presented content engineering process has been developed and evaluated in the projects ELIE (E-Learning in Engineering) [55] and mobiLearn [56]. It has been enriched with concept mapping, not only facilitating note taking through providing a structure according to the interview, but rather encoding domain structures that can be annotated with additional information. Of particular interest are domain-specific refinements and educational metadata.

The approach comprises five main steps: preparation, preliminary document analysis, structured interview, extended document analysis and mapping of didactics, and finally, the actual content authoring and delivery to an e-Learning system (Figure 9). The core process steps aim to identify domain-didactic items based on relevant learning items and interview findings from domain experts, and to specify didactically enriched learning content. 


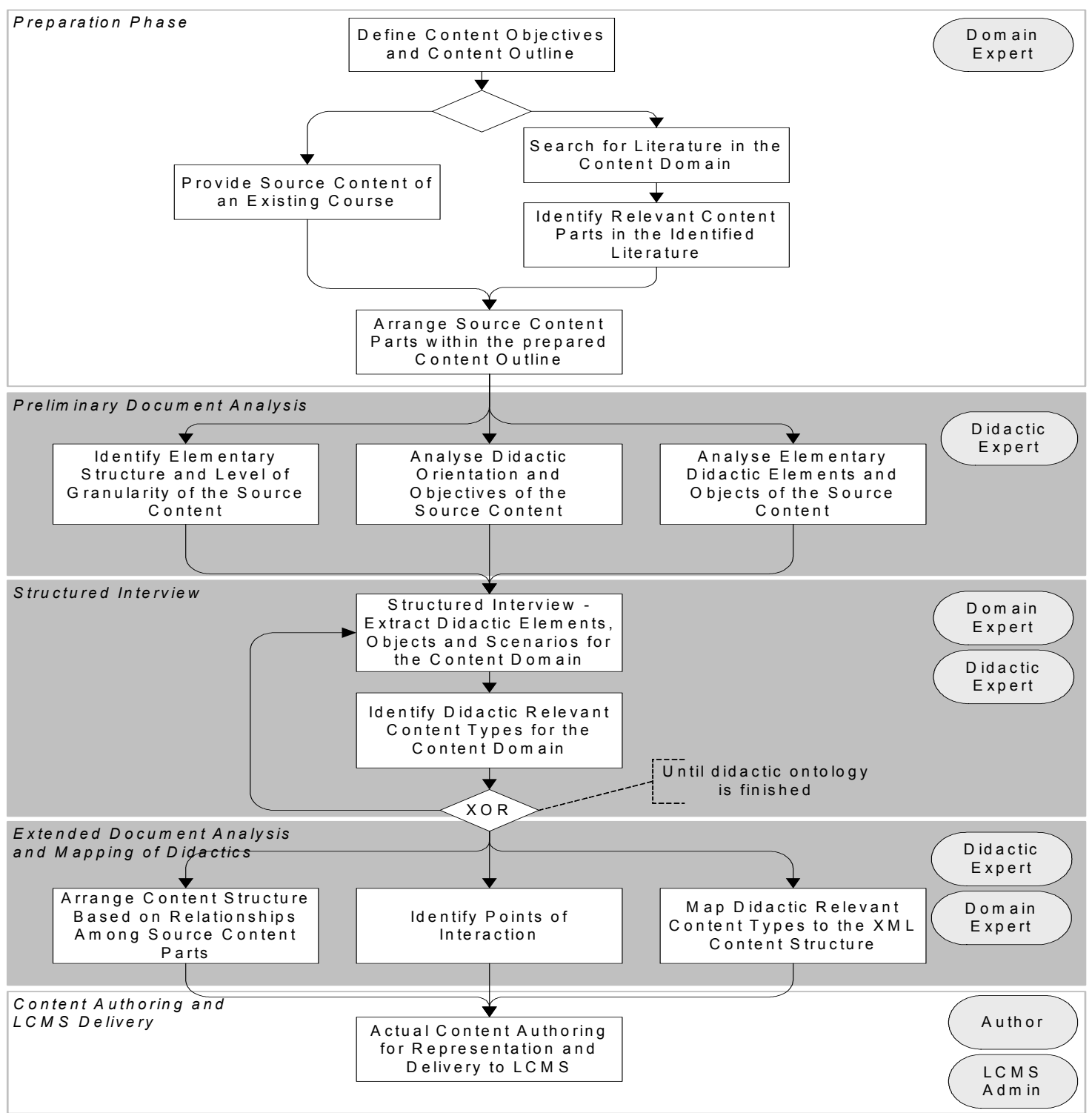

Figure 9 - Process map for e-learning content engineering according to [55]

In the course of the preparation phase, resources for content development have to be identified, mainly by educators who are also domain experts. A content outline map, including building blocks of a course, such as learning goals, target learner group, basic structure, depth and granularity of content is specified (cf. [57]. According to that structure, resources can be structured and analyzed. A set of resources forming an educational baseline serves as input for the didactic enrichment (tagging) process. Figure 10 shows an outline map (step 1).

It contains relevant topics for Business Process Management for beginners in Business Information Systems at the university level. As such, it reveals a stepwise from theory-to-practice introduction. A possible starting point are fundamentals in modelling and models (upper left corner) before either introducing theoretical models of organizations (upper right) or business process modelling (center). Business process execution is grounded on understanding modelling organizations in terms of processes. 


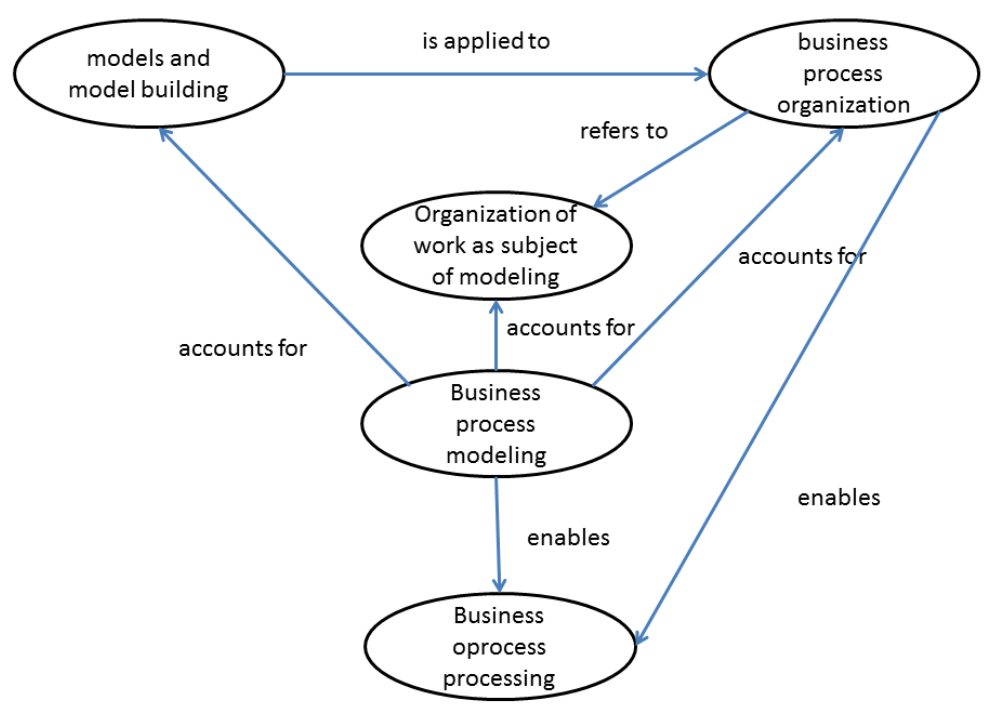

Figure 10 - Content outline map for business process management

Figure 11 shows the annotated map (step 2). The elementary structure displayed in Figure 10 allows annotating:

- Refinements of the fundamental structure, such as detailing business process execution in terms of performance engineering and workflow management (lower left part of Figure 11);

- Essential aspects, such as "structure" and "behavior" for understanding "business process organization";

- The assignment of elementary didactic tags along refinements, such as "case study", "definition", "explanation";

- Information on didactic orientation according to objectives of a course, such as assigning theory- or practice-laden didactic terms to topics, e.g., "tool" to "business process processing".

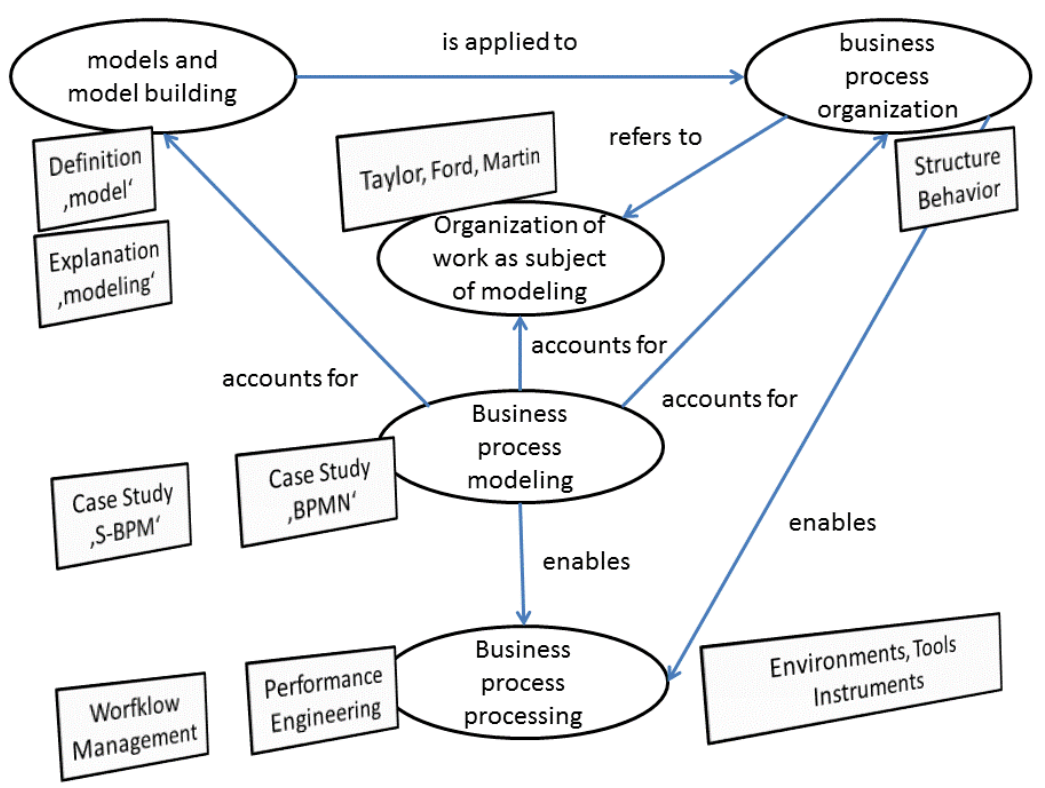

Figure 11 - Annotated structure map 
In the course of the preliminary document analysis, source content chunks and documents are scanned to identify the level of granularity, content for orientation and navigation, and elementary didactic elements. The level of granularity of resources can be quite different: presentation slides, textbook elements, animations, apps. In the concept map annotations are used to identify relevant content items. Depending on the intended use of the content different levels of detail may be useful. Finally, elementary didactic elements, such as definition, example, case study, can already be identified. A concept map structuring all sources of relevant input also contains the rationale why this element should be included, relationships between the documents, and meta data, such as codality of information (video, text etc.). Hence, the final map contains all relevant associations (links) including navigation and navigational guidance. It forms the guide for the structured interview to validate the findings so far.

The structured interview with the educators concerns the following issues [55], supported by a structured mind map (see Figure 12) to condense all provided inputs:

Organizational Context. Organizational issues include content profiles, learner profiles and the organizational learning environment:

- number of educators and learners;

- current didactic quality of resources, including meta-data of different kinds;

- structure and procedure of educating and facilitating learning;

- criteria most important for facilitating learning processes, ranging from quality and adaptability of content to learner satisfaction and innovation;

- target group(s) in terms of background, motivation, literacy, learning style, professional orientation (technical, business, a.t.l.);

- guiding principles of learning processes: to make new knowledge accessible; to practise and deepen linking knowledge; to link existing knowledge; to embed knowledge in a global context;

- type of education in terms of learning (self-directed/instructor-driven, project/assignment-driven etc.) processes.

Individual Positioning. This section should clarify the individual approach of educators with respect to support learning processes:

- time spent with learners (either face-to-face or in virtual settings);

- fundamental individual didactic principles and preferences, e.g., less is more;

- potential of (re-)designing learning resources.

Learner/Learning Support. It comprises:

- activities of educator along

- preparation phase, e.g., selection of content elements, establishment of specialized didactics, learner consultancy;

- implementation of the course, e.g., classroom teaching, feedback sessions, quality checks;

- assessment;

- evaluation;

- improvement of learning resources, didactic approach, and tools (based on evaluation results);

- didactically motivated content elements utilized for learning (codification such as text, pictures, multimedia, drawings; content types such as examples, cases, definitions, directions; interactive elements);

- structure of learning resources: linear/sequencing, linked/hyper medial, hierarchical, hybrid;

- completeness of learning resources with respect to didactic design;

- organization of learning support, including feedback to learners;

- grading and examination. 
Communication. Social interaction and skills of the interviewed educator refer to:

- frequency of contact with other stakeholders (educators, learners etc.);

- particularities of interaction, such as hot potatoes, organizational issues, tools, taking lead.

Technical support. It addresses:

- categories of ICT-tools, such as content management, social media;

- technical interface issues when linking of two or more tools is required for learning support;

- meta-cognitive (learning-to-learn) support tools;

- learner profiling, identity management, and integrity/security issues.

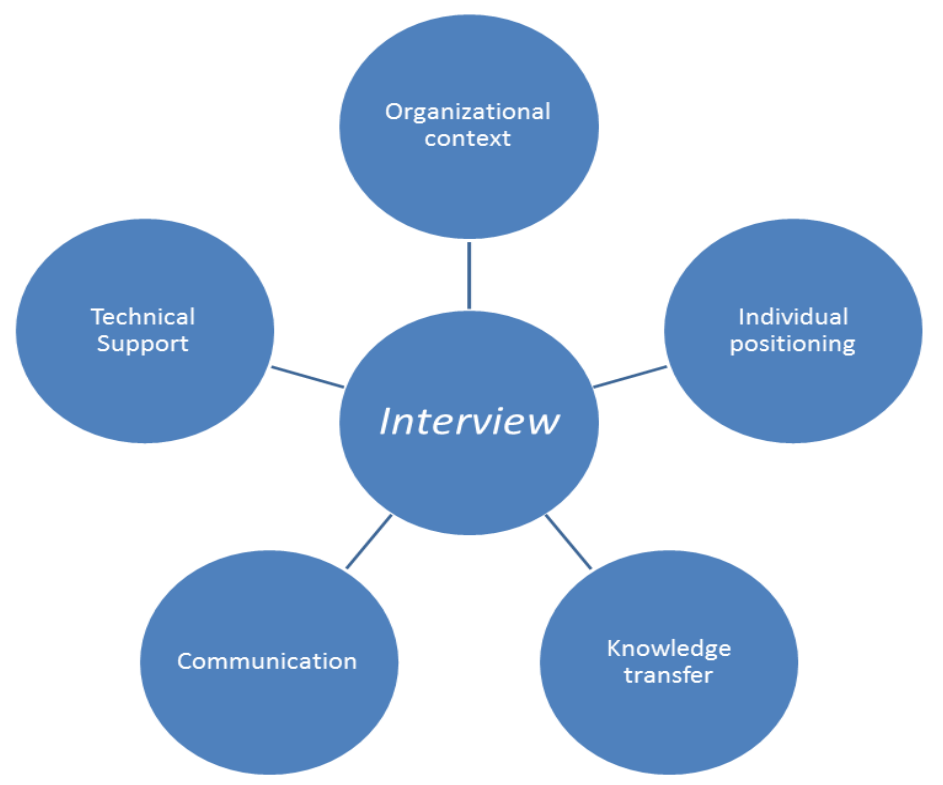

Figure 12 - Structure map for interviewing and result presentation

The structured interview should clarify individual, organisational and technical aspects of the learning support process. In the core part of the interview, didactically motivated elements such as didactic content types, interactive elements etc. are identified by the interview partner.

In the next phase, the didactic elements and structures are mapped to the (XML-)content structure. In case content has been already tagged, as some text books are generated according to metadata or didactic ontologies (cf. [58-61], w31.de) these data can also be generated automatically (cf. [62]) or semi-automatically (cf. [63-64]).

Since the early days of e-learning the need for encoding didactic quality into content has been demanded (cf. [65-66]). Content elements should not only contain, but also visualize meta-data, such as definition, for orientation and selection. Figure 13 shows such an approach (cf. [55-56]). Learning units are part of modules courses are composed of. They contain content blocks with various domain- and education-relevant tags assigned to content elements. These elements can be text, graphics, video, or audio information.

Table 1 shows part of a typical didactically enriched structure developed for a course on Business Process and Communication Modeling at the University of Linz, Department of Business Information Systems. The course is given as an introduction to BPM to students in the Business Information Systems curriculum in the first year of the corresponding Bachelor degree program. Modules and Learning Units can also be shared with other course (cf. [67]), either in Computer Science or Business Information Systems, such as Communications Engineering. In those cases the assignment of metadata (Block types in Figure 13) needs to be reconsidered (cf. [68]), as, e.g., some Definition in Computer Science may need to be re-categorized as Explanation in Business Informa- 
tion Systems due to its explanatory character when focusing on application of computer science theories and concepts.

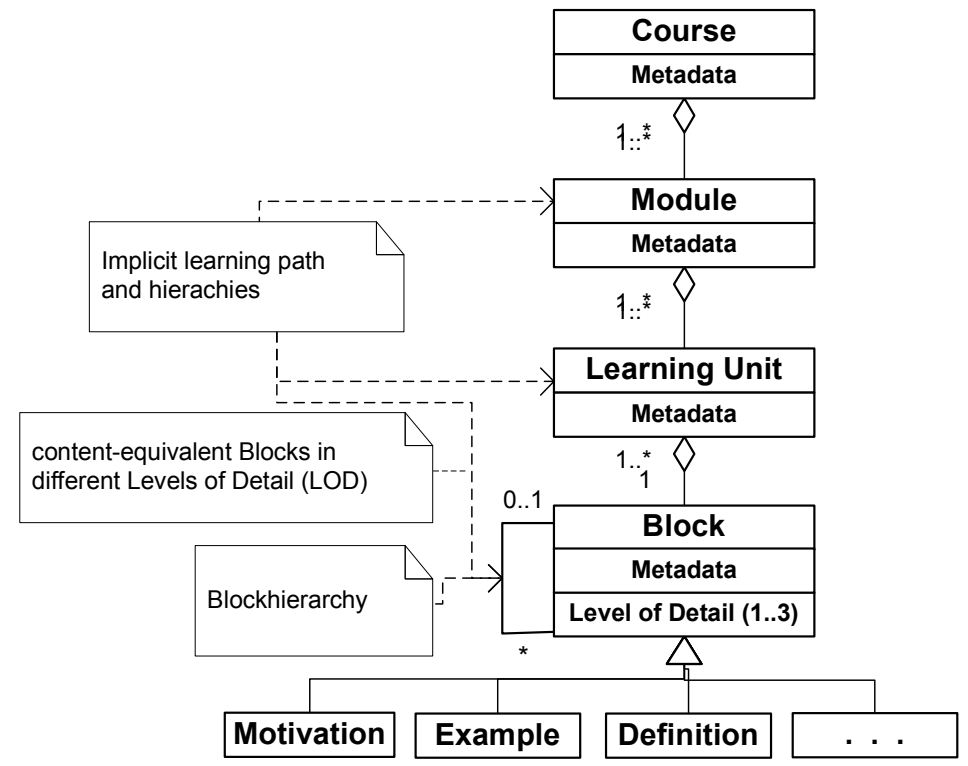

Figure 13 - Educational metadata structure

Table 1 - Example of tagging a BPM content structure

\begin{tabular}{|l|l|l|l|}
\hline Module & Learning Unit & Block & Didactic Tag \\
\hline $\begin{array}{l}\text { Process } \\
\text { Engineering }\end{array}$ & $\begin{array}{l}\text { Development of Process } \\
\text { Organizations }\end{array}$ & $\begin{array}{l}\text { Business Process Re- } \\
\text { Engineering }\end{array}$ & $\begin{array}{l}\text { Background } \\
\text { Information }\end{array}$ \\
\hline & & Design & Case Study \\
\hline & Performance Engineering & Explanation \\
\hline & Implementation & Example \\
\hline & Process Simulation & Objoctogy & Explanation \\
\hline & & $\ldots .$. & Content \\
\hline
\end{tabular}

Tagging follows the structure of the content outline map shown Figure 10, leading to the following modules (see also Figure 14 - navigation area on the left side of the screenshot):

- Introduction, providing the relevance of the field;

- Models and modeling, giving some background on abstraction and representation;

- Organizations and processes, introducing the nature of business processes and their history in Organization Science;

- Process modeling, detailing functional, object- und subject-oriented approaches to business process modeling, with practical guidelines on how to construct models in the respective paradigm;

- Process engineering, providing fundamentals of performance engineering, architecture designs, and workflow management, in order to implement business process models by ICT systems. 
In Table 1 one of the modules, "Process Engineering", is detailed with respect to some of its learning units (Development of business organizations, Workflow Management, Process Simulation), and its content elements (blocks), and their tags for the first learning unit.

In addition to tags distinguishing various levels of detail has turned out to be useful for useful for targeted content delivery. Using several LODs (Level Of Details) content developers can structure learning resources on three different levels of granularity. A common instantiation of that concept is to provide slides for classroom presentation on LOD1, text book elements for reading and self-studies on LOD2, and additional information or further resources (links, files, videos, and the like) for exam preparation and in-depth studies on LOD3.

For learners tags are visualized when content elements are displayed. The content area in the center of the screen (see Figure 14) corresponds to the work space of stakeholders. Navigation is provided initially as tree view on the left side of the screen. It supports nesting of content elements, in order to facilitate structured access to content elements, such as displayed for Process Engineering on the left bottom of the screen in Figure 14.

Explicit tags also allow filtering according to learning styles, e.g., selection of all examples of a learning unit, in case a learner is more practically oriented when acquiring knowledge. Given the proper functionality (see third entry from left "Filter" in the toolbar beyond the navigation space), the LSS (Learning Support System) displays only those parts in the navigation and content area that contains the selected tags. Hence, both, domain structures, and didactic expertise contribute to semantic richness of the provided BPM content.

In Figure 14 on the left side of the screen a tree view for navigating the nested content is shown, whereas in the center the selected content is displayed, in this case "Development of process organizations" being part of the module "Process Engineering"). The tags are "background information" (Hintergrundinformation) and "practical guideline" (see marked areas on the right side of the screen) concerning some text to motivate developing process-based organizations, and a practical guideline on the development of process organizations revealing BPM phases that should be followed in the course of development.

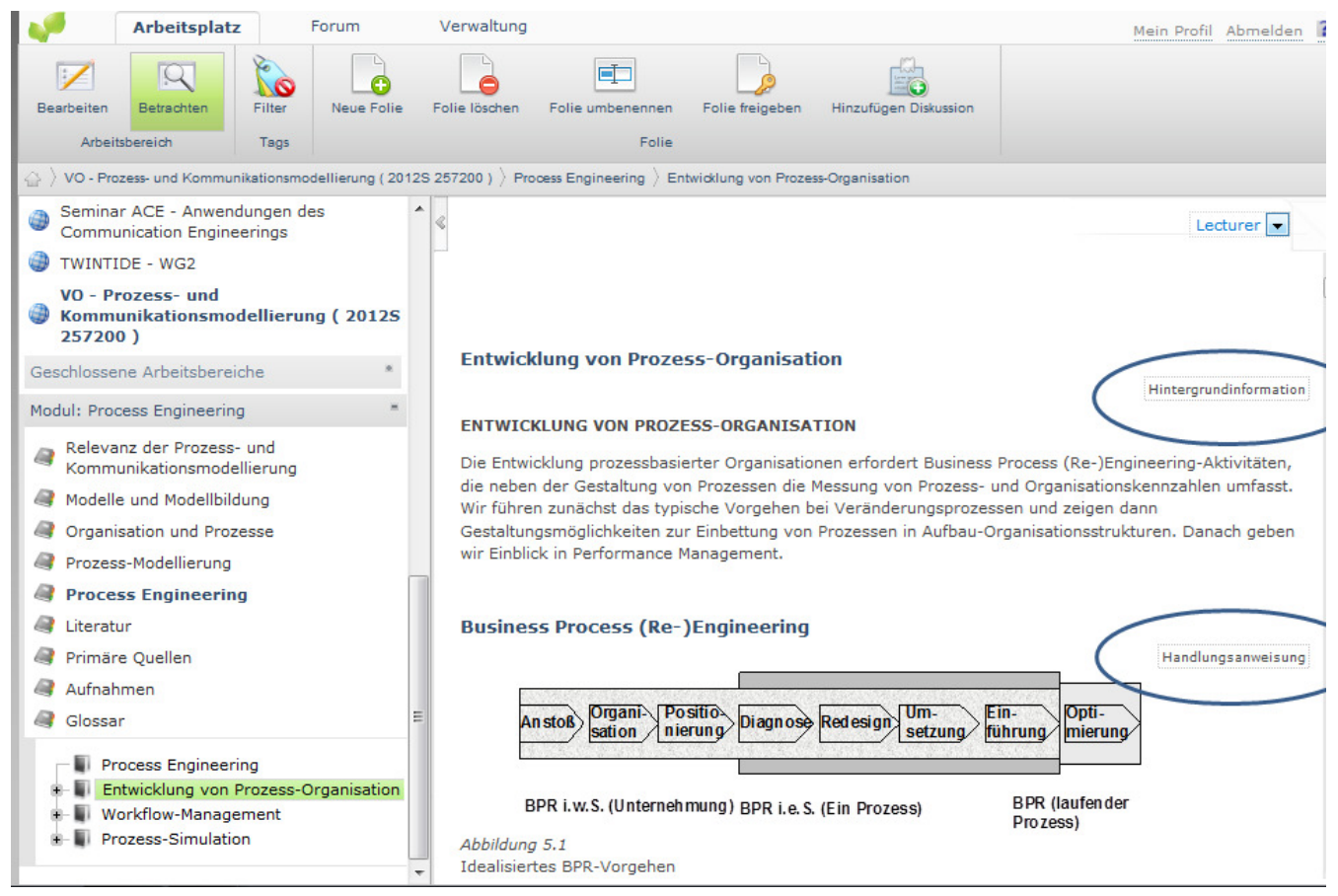

Figure 14 - Tagged BPM content - "background information" and "practical guideline" on the development of process-based organizations 
The latter case reveals the intention of tagging, expressing the context how the content is addressed and could be used. For learners that should find orientation how to set up BPM projects, and participate in BPM lifecycle activities the tag "practical guideline" indicates this educational intention. In case learners are more focusing on becoming acquainted with frameworks, e.g., when comparing lifecycles from various BPM approaches, they could be supported effectively using a tag like "operational frame of reference" or "value chain".

\section{Semantic Navigation}

Navigation makes up most of the user's experience (cf. [69]). Consequently, navigation features should facilitate the access to domain- or user-relevant information including content and its manipulation features. When using those features users should build up and maintain a coherent mental representation of the traversed environment, the so-called cognitive map (cf. [70]). Such a representation serves as a baseline for learners and facilitators when interacting with a learning support system (cf. [71]). However, for content-rich applications there is no consensus on (re)presenting content and manipulation features in a user-centered way [72-73].

The learner support presented so far (see previous section) featured the dynamic selection of meta-data, such as "explanation" which allows learners navigating through content and experience it individually. Its design is led by domain concepts which can be created by mining techniques mapping from documents [74], however could be utilized for adapting to learner needs, e.g., planning individual learning paths [61]. Tseng et al. [62] constructed concept maps for achieving adaptive learning. Hereby they automatically created predefined concept map of course descriptions [75] that could be adapted to individualize learning paths. They can help educators and learners to locate and assign learning resources according to recognized learning goals. However, intentional elements need to be visualized and accessible interactively (cf. [76]).

In the following we review the concept map based tool developed by [77] that allows encoding of intentional information dynamically, such as learning objectives, domain and didactic meta-data. Using the LSS shown in Figure 14 they had found that the deep hierarchy levels had been timeconsuming for learners with respect to navigation, and thus, were hindering learning processes. They developed an associative navigation design, enriched with educational and domain-specific metadata. It allows individual exploration of content, and is displayed as concept map. Learners select learning their paths according to the prepared links and may navigate beyond hierarchies (as encoded in the tree view), and across domains or courses.

Figure 15 depicts a concept map for the learning unit on "Enterprise Architecting" being part of "Process Engineering". Educational metadata (motivation, definition, etc. - see also Figure 16) semantically describe links to information resources. Hence, the associative navigation provides learners additional structural navigation information that shapes their learning paths.

Individualization support considering the associative navigation is similar to the hierarchic approach presented in section 1. It is enabled through features like annotating a concept map and its elements, editing such as adding individual concepts, and filtering links to information resources according to didactic content types, content codality, or user profiles and preferences. Compared to the hierarchic approach, the concept map approach also enables annotation referring to concepts, relations, and links to resources. 


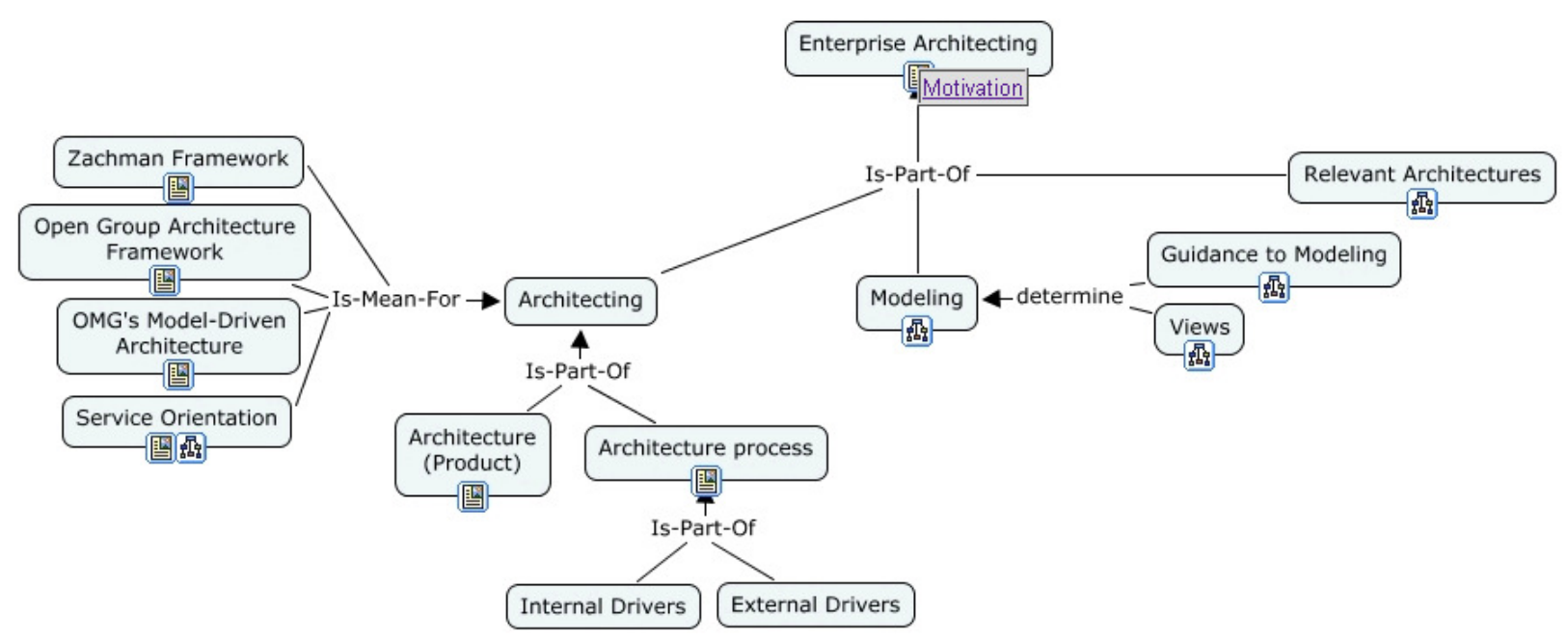

Figure 15 - Didactically enriched concept map navigation

In order to support both approaches, a polymorph representation scheme has been developed based on the ISO standard of Topic Maps (cf. [77]). For the implementation of the dual navigation approach the differently organized information structures have been recognized applying an intertwined view concept. The following view types match the different approaches: Learning content (structure) view, linking and individualizing view, domain context, and access context:

- Learning content (structure) view. This view contains didactically enriched learning content typically authored by educators. It serves to present the basic structure of learning resources and communication features. Regarding the given navigation designs, this view includes parts of the hierarchic navigation design. To support authoring of learning resources in this view, didactic topic map templates are useful (cf. [78]). Such templates aim to ensure consistent authoring and finally consistent navigation. Furthermore, didactic topic map templates allow the consideration of different didactic attempts and singularities of knowledge.

- Linking and individualizing view. The aim of this view is to allow users embedding arbitrary content in their individual learning process or in collaborative learning processes, and thus supporting knowledge transfer. Within this view (individual) semantic relationships between arbitrary content elements are represented, e.g., relationships between learning content and communication items, learning content and domain concepts, relationships between learning content/domain concepts and additional information in the web. Nevertheless, content elements (such as block, communication item, domain concept) provide the focus and serve as anchor to represent associated information. Further aspects of individualization such as annotations, meta-data or comments are also represented within this view. Thus, linking and individualizing views allow recording the knowledge construction process of learners (cf. [79]). Moreover, through allowing relationships between arbitrary content elements new navigation paths can be offered in contrast to hierarchy-driven navigation paths. Since linking and individualizing views record the knowledge construction process of learners, for learning in teams sharing and merging facilities for views are necessary to support collaboration among learners. Topic Maps provide an integrative concept to that respect. For efficient migration Published Subject Identifiers (PSI) are recommended (cf. [80]).

- Domain context view. Within this view concept of a given knowledge domain and respective associations are represented. Additionally, this view includes domain-overlapping relation- 
ships. Besides concepts and associations, relationships between concepts and information resources are depicted within the domain context. Information resources can either be arbitrary content elements of the learning resources or other information resources, such as external web pages. In order to allow individualizing the description of a given domain, individual views can also be represented upon domain contexts.

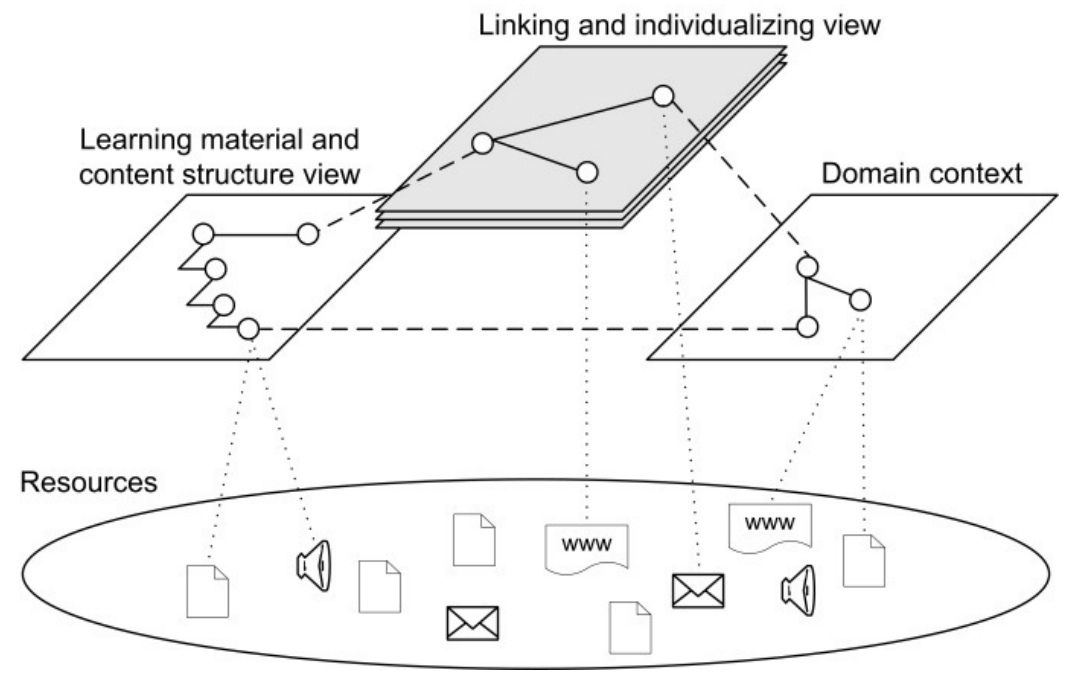

Figure 16 - Relationships between main views

- The access context view supports adapting navigation and presentation of content according to different user preferences, devices or learning situations. It allows adaptive navigation experience for learners, e.g., by retrieving content in different levels of detail (e.g., bullet points LOD1, text - LOD2, additional information - LOD3) and different codalities (e.g., text, audio, video).

The integration of the above mentioned views provides a holistic perspective on learning content embedded in individual, didactic, communication, and domain context. Considering navigation in such a multifaceted environment, content elements provide a focal point of learning processes. Content elements represent anchors for switching between different views (e.g., domain context, learning resources and content structure view) or for combining different views.

Finally, reconsidering Topic Maps for the representation of the given views, it is necessary to distinguish the representation of structure (topics+associations) and the representation of content (occurrences). Structure focuses on navigation and supports retrieval of content, while occurrences represent the link to information resources (content). Different statement types support filtering of navigation paths (cf. association types) as well as content types (cf. occurrence types). For instance, occurrence types allow representing various codalities (e.g., audio, video) for a topic, and hereby selecting content according to the desired codality. Annotating learning content (using hierarchic navigation) with a concrete domain concept allows switching between hierarchic navigation and concept map-based navigation (see Figure 17). Besides switching between different navigation designs, the topic map representation approach allows:

- flexible embodiment of didactic information into the navigation design;

- domain-specific adaptation and navigation;

- re-using of content elements in different contexts (e.g., traditional tree view, concept map);

- filtering content according to didactic type, codality and granularity;

- filtering navigation paths (associations) within the concept map navigation; 
- individualizing of learning resources (e.g., linking blocks or concepts with communication items in order to represent context-sensitive discussions).

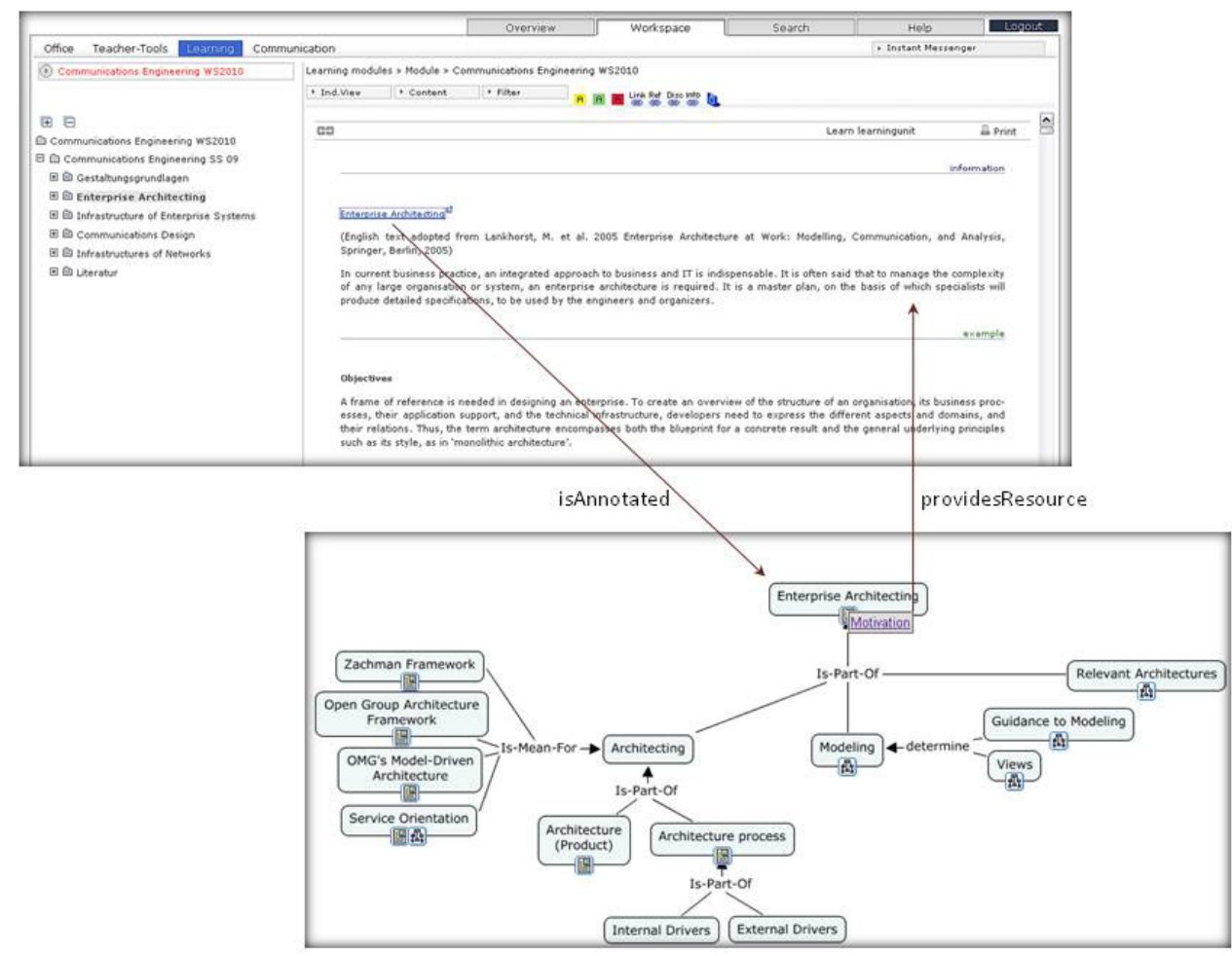

Figure 17 - Linking hierarchical and associative navigation design

Such an implementation enables a highly flexible learning support system, as it can be adapted to user preferences and navigation styles promoting individual learning experiences. Learners who have been using the associative navigation design mentioned that it helped them to get an overview regarding the content of the lecture and to identify relationships between content elements. However, they indicated to have used the concept map in addition to the provided text book for the lecture and not as primary source when learning. The content types displayed in the associative navigation have been experienced to support learner navigation. The depicted relationships between concepts as part of associative navigation have been intelligible to most of the learners.

In this way the empirical findings confirmed some expected benefits, and affirmed that both navigation designs are used by learners complementary [77]. While associative navigation design seems to be used by learners primarily to get an overview of a domain and to recapture associations between the domain-specific concepts and content, hierarchic (tree) navigation seems to be preferred by "top-down learners", working with content primarily in a linear way.

\section{User-/Usage-oriented Design Spaces}

From the findings in the previous section, in particular for semantically enriched navigation design various design dimensions to provide meaning of learning content have become evident - see also Figure 18:

- Subject-inherent and domain-independent elements. They can be found in most of the educational subjects, as they constitute disciplines. Among these elements are origin, concept, paradigm. In BPM typical origins are organizational development or software engineering, concepts 
are modelling elements to represent business processes, and paradigms are communicationorientation and functional specification.

- Subject-inherent and domain-dependent elements. These elements are typical for certain domains, and allow differentiating domains, such as software project management and BPM. In BPM typical instances for domain-dependent elements are business process models, analysis methods, life cycle. They concern fundamental elements to understand the field.

- Learning-inherent elements that are domain- and situation-dependent. This category refers to elements directly influencing the style of presentation, location, and reception of resources as well as learner behaviour (cf. [81]). For instance, in progressive education self-regulated learning, exploration, and informed problem solving are of eminent importance. The domaindependence is given by looking whether the domain, such as BPM, allows such an approach. The same holds for the situation, as the format of lectures influence learner behavior. A course providing project assignments is likely to allow self-organized problem solving in contrast to focused method training.

When it comes to implementing didactic settings the underlying services are of importance (cf. [82-84]). More particular, a variety of tools support e-learning today and are part of respective environments. Besides traditional content management Web 2.0 technologies, such as blogs, wikis, chat rooms, video streaming, a.t.l. are widely used [84]. Few of them aim to create an integrated learning support system [85-86]. Hence a mapping from didactic requirements (sees section 1.2) to services allows for traceability of the development process. Hereby a middle design layer (see Figure 19) as a focal point in terms of feature bundles turned out to be useful.

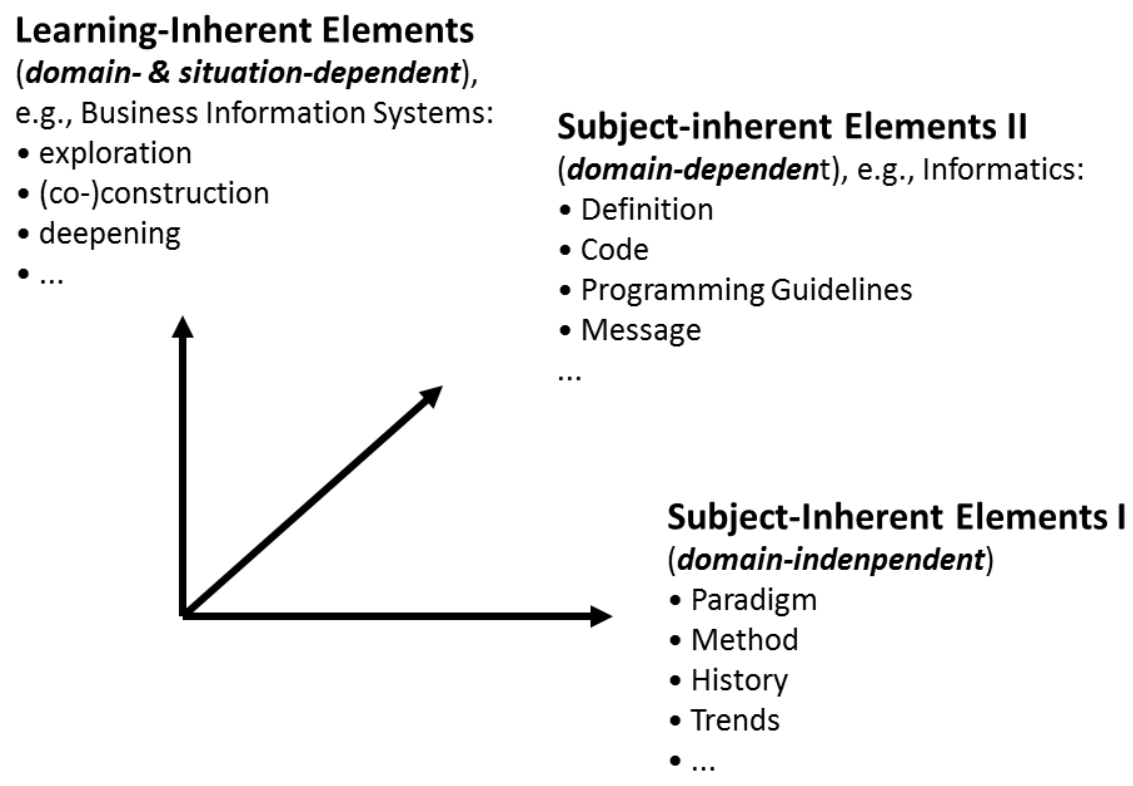

Figure 18 - Categories of design elements

Once the underlying education scheme is considered to be a starting point for learning design (cf. [87]) features need to be derived from pedagogic elements in terms of technological functionality in the course of development. Concept maps also help to structure and guide this process. In Figure 19 the top layer consisting of domain and didactic structures is related to feature bundles located in the middle layer that allows identifying classes of systems for implementation and refining them in terms of their specific features or services (cf. www.archimate.org).

Figure 20 exemplifies the principle of this design mechanism based on input presented in the previous sections. For the sake of intelligibility the link structure of the map is only sketched 
between the top and the middle layer. The middle layer exemplifies typical "design cornerstones", such as a feature bundle for content management, integration social media into content management, and supportive transfer structures. Each set of features is detailed in terms of tools or tool sets in the bottom layer.

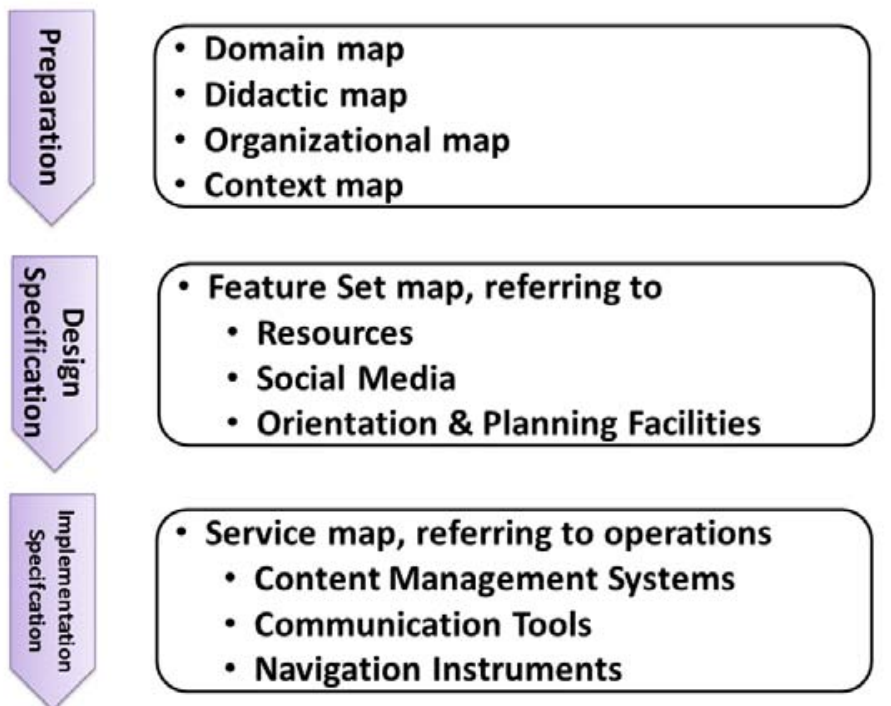

Figure 19 - A layered approach to a user-/usage-centered learning design space

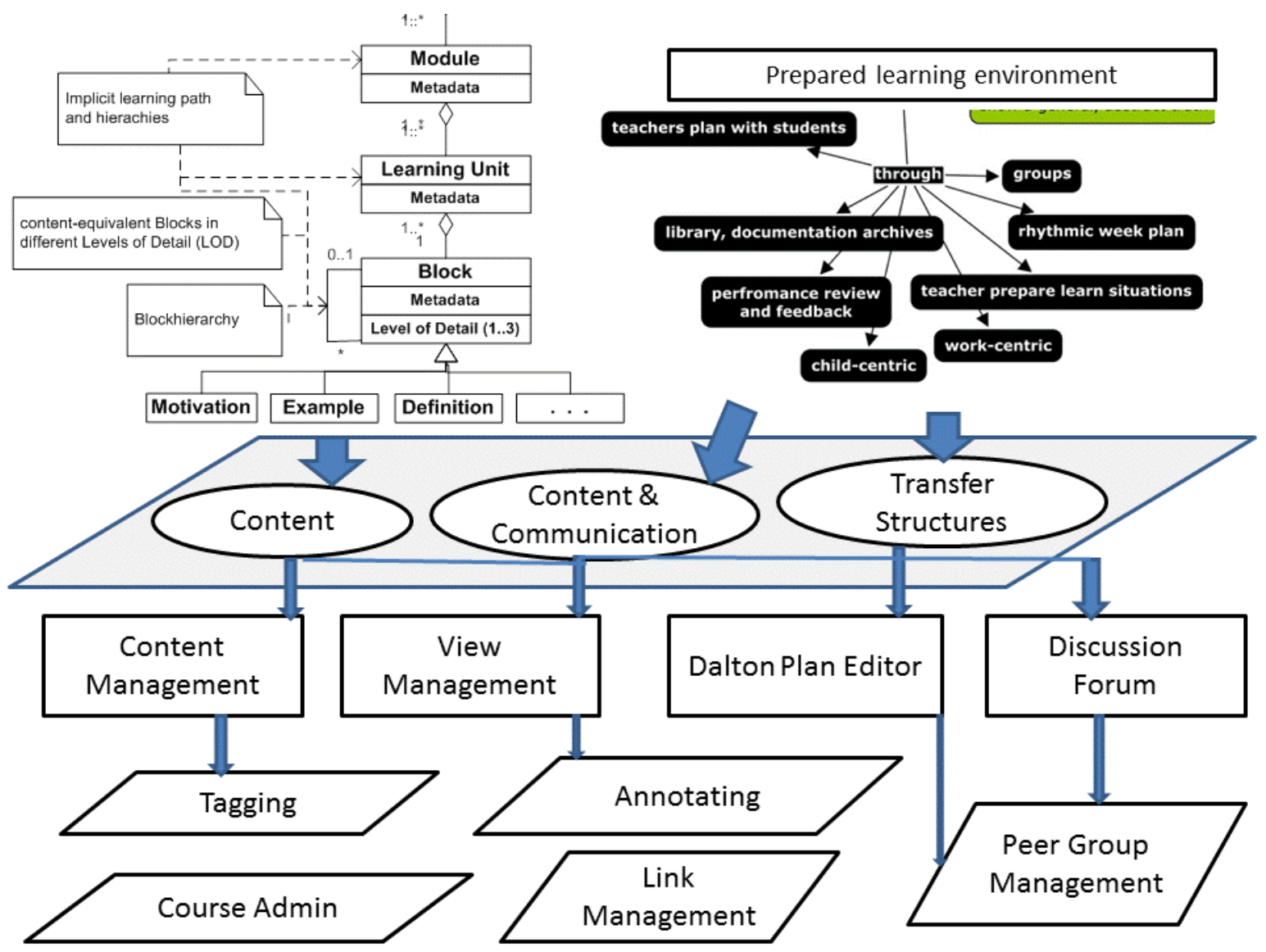

Figure 20 - Schematic instance of design map 
For instance, following the progressive education approach, the Dalton Plan as introduced by Parkhurst [88] has been implemented [31,49]. The Dalton Plan primarily uses assignments and feedback graphs in conjunction with bulletin boards and conferences. An implementation in a learning support system requires a prepared environment as shown in the right top of the figure (extracted from Figure 8 - requirements). From the middle design space layer Content \& Communication and Transfer Structures are addressed in line with recent findings with respect to effective e-learning processes [4].

According to the concept mapping guidelines, each element of the upper layer (encoding the didactic and domain concepts) can be related to one or more elements of the upper and middle layer. For the Dalton Plan implementation a link needs to set between 'teachers plan with students' (upper layer) and "transfer structures", as the Dalton plan is based on a work plan structuring learning steps.

Using the Dalton Plan editor (systems and specific feature layer in the design map of Figure 20) the different parts of Dalton Plan assignments and their relationships can be specified. Assignments organize learning processes by detailing problems and providing descriptions, namely in terms of documentation (Written Work) and cognitive activities (Memory Work) involving individual and group tasks.

The Dalton Plan facility enables deadlines and providing feedback to learner achievements (see Figure 21 and 22). Feedback graphs allow transparent progress reports. Meetings and so-called conferences are also part of the Dalton Plan. They can be scheduled on a regular basis or announced on the bulletin board. Figure 21 shows the assignment editor for specifying work plans, and feedback graphs (Figure 22) implemented using a web 2.0 technology stack (cf. [89]) in the Learning Support System already presented above. Each learner can be (re)presented by a feedback graph once working on a specific assignment. For each assignment all currently involved learners can be displayed according to their state of affairs, both in terms of self- and educator assessment.

In general, the introduced design space approach for user-/usage-centered learning designs bridges the gap between educational requirements and technical system features by a middle layer that serves top-down and bottom-up specifications:

- Educational inputs can be refined to requirements, either in terms of domain, didactic or situational structures (top layer);

- For each of these maps from the top layer one or more points of reference in terms of bundles (of features) in the middle layer can be defined, e.g., content management for didactic elements being part of learning units;

- Systems utilized for implementation can be refined in terms of their features (bottom layer)

- Each feature can be assigned to a system which can be assigned to a class of systems (bottom layer);

- Each set of features (middle layer) is implemented through (a set of) systems (bottom layer), and vice versa, each class of systems, system or feature can be assigned to a bundle of features on the middle layer.

Finally, all neighboring relationships for design and implementation, such as using the Dalton Plan editor together with existing Social Media, may be specified on the top and bottom layer. The middle layer elements should only be linked to upper and lower layer elements, for the sake of coherent assignments of bundles (of features) to systems or system features (bottom layer). Thus, the middle layer may not be considered a separate topic map. 


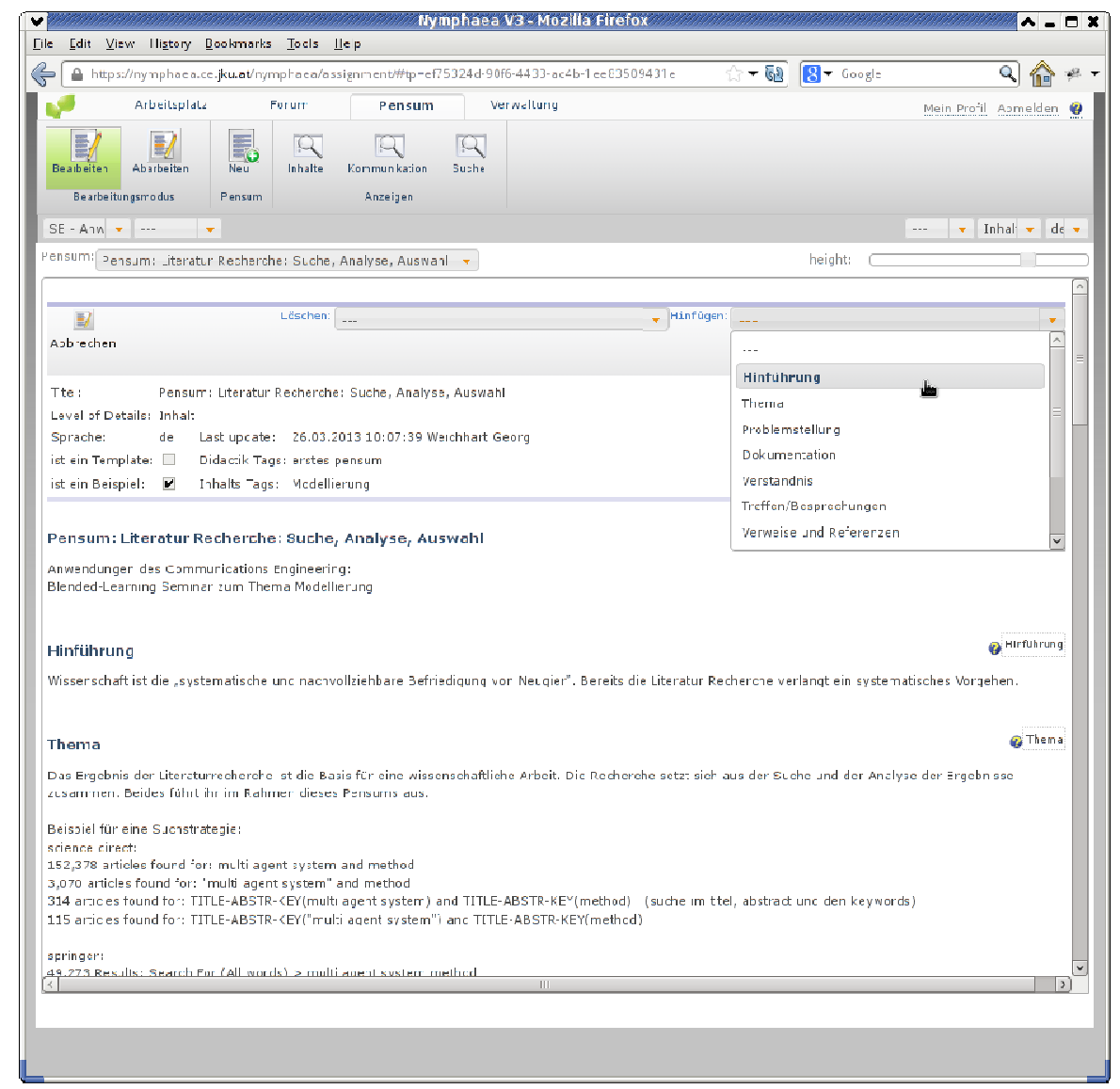

Figure 21 - Dalton Plan editor [31]

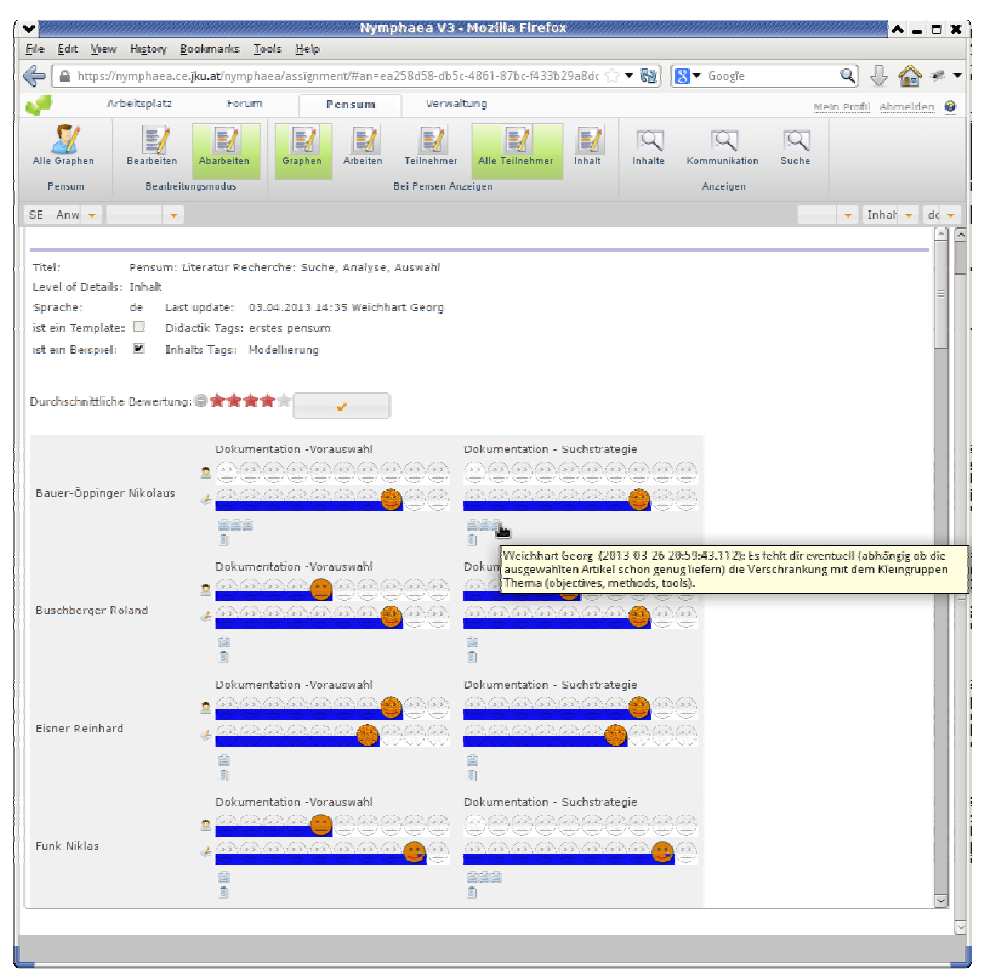

Figure 22 - Feedback graphs [31] 


\section{Conclusions}

The development of learning support systems seems to be an open puzzle, both in terms of concepts and instruments when putting concepts to practice. This contribution can be seen as a trial to use concept maps as representational glue to stabilize parts of an evolving puzzle, once its parts have been identified and need to be aligned, starting with educational intentions, and proceeding with preparing a supportive learning environment based on meaningful content and learning process specifications.

When intertwining emotional, social, cognitive, and technological issues means of orientation and documentation become essential, not only for those who are carrier of these processes, but rather for those who initiate and facilitate these processes, namely educators, content providers, and developers. Concept mapping is easy to learn and concept maps are easy to use when (representing information in a context-sensitive way. They can be used to generate and organize knowledge for sharing (e-)learning expertise in a straightforward way.

We started out with articulation work on educator knowledge and education-relevant mappings for learner-centered design. The design spaces we could open up allow proceeding with content production and navigation design based on intentional and meaningful design elements. Meta-data are key to implementing design maps with Web 2.0 technologies which can be captured in a layered design space according to generic feature classes.

Educational metadata stemming from domain didactics can be effectively used for content and navigation structuring. Concept map-based navigation design complementary to nested tree structures can be created using topic maps and support learners along individualized learning processes. Hence, the primacy of didactic design together with dynamic adaptation forms the base for user- and usage-centered interaction.

Future developments will focus on deepening the understanding of dual design and navigation representations when starting with articulating educational knowledge. We are working on aligned tool support to couple the reflection of designs and their effectiveness in learning processes to tools adapting to the represented knowledge structures. As such, e-learning and knowledge management environments could become a living design memory in the sense of dynamically informed end-user computing involving learner and educators according to Dewey's intention. Such an approach does not only allow dynamic and personalized adaptation of content, navigation and learning support structures, but keeps track of previous designs including their effects when being in use. Hence, learning cycles for e-learning could be coupled directly with the actual learning processes they aim to support.

However, the underlying technologies, such as intelligent content management and social media, need to become part of an integrated system, in order to provide seamless stakeholder support. Considering today's learner communities, students very likely want to use those social media they are perfectly acquainted with and thus, use them as integral part of their daily routine, such as facebook (facebook.com). These tools need to be interoperable with learning support systems, since replicating functionality might not lead to the intended effect of non-disturbing learning support. Hence, future research will also focus on interoperable technical systems that are utilized implementing the content structure and feature chains specified in the design space.

\section{Acknowledgements}

We thank the IANES (FP 7 People Programme - Industry-Academia Partnership and Pathways, People Grant 286083, Interactive Acquisition, Negotiation and Enactment of Subject-oriented Business Process Knowledge, www.ianes.eu), and nymphaea team (nymphaea.ce.jku.at) for their continuous support of our research. 


\section{References}

[1] Feldstein, M. Ubiquity Symposium: MOOCs and Technology to Advance Learning and Learning Research. The MOOC and the Genre Moment, in: Ubiquity, 2014(9), 1-9, ACM, DOI: 10.1145/2591681, download from http://ubiquity.acm.org, 16.9.2014.

[2] Siemens, G. Connectivism: Learning as Network-Creation, 2005 http://www.elearnspace.org/Articles/networks.htm/, download 16.9.2014.

[3] Garrison, D.R. E-learning in the 21 st century: A framework for research and practice, $2^{\text {nd }}$ ed., Routledge, 2011, New York.

[4] Dabbagh, N., Kitsantas, A. Personal Learning Environments, Social Media, and Self-regulated Learning: A natural Formula for Connecting Formal and Informal Learning, in: The Internet and Higher Education, 2012, 15(1), 38.

[5] Gilbert, T. F. Mathetics: II. The design of teaching exercises. Journal of Mathetics, 1962, 1(2), 7-56.

[6] Scott, R. $\boldsymbol{O}$. Mathetic and progressive chain strategies for instructional sequencing (Doctoral dissertation, University of Michigan. 1968.

[7] Eichelberger, H., Kohlberg, W.-D., Laner, Ch., Stary, Ch., Stary, E. Reformpädagogik goes e-Learning. Neue Wege zur Selbstbestimmung von virtuellem Wissenstransfer und individualisiertem Wissenserwerb, 2008, Oldenbourg, München.

[8] Leclercq, D., Donnay J., De Bal R. Construire un cours programmé. Bruxelles, 1977, Labor.

[9] Duckworth, E. „The Having of Wonderful Ideas“ and other Essays on Teaching and Learning, Teachers College Press, $2^{\text {nd }}$ ed., 2006, New York.

[10] Deroin, R.E., Fritzsche, B. Salas, E. E-Learning in Organizations, Journal of Management, Sage, 2005, 31(6), 920-940.

[11] Novak, J., Canas, $\boldsymbol{A}$. J. The theory underlying concept maps and how to construct them, Technical Report IHMC CmapTools 2006-01, Florida Inst. f. Human and Machine Cognition, 2006, Pensacola.

[12] Moon, B., Hoffman, R. R., Novak, J., Canas, A. (Eds.). Applied concept mapping: Capturing, analyzing, and organizing knowledge. CRC Press; Boca Raton, FL. 2011.

[13] Markham, K. M., Mintzes, J. J., Jones, M. G. The concept map as a research and evaluation tool: Further evidence of validity, in: Journal of research in science teaching, 1994, 31(1), 91-101.

[14] Novak, J. D. Concept mapping: A useful tool for science education, in: Journal of research in science teaching, 1990, 27(10), 937-949.

[15] Kinchin, I. M. Using concept maps to reveal understanding, in: School Science Review, 2000, 81(296), 41-46

[16] Peris-Ortiz, M., Benito-Osorio, D., Rueda-Armengot, C. Applying Concept Mapping: A New Learning Strategy in Business Organisation Courses, in: Innovation and Teaching Technologies. New Directions in Research, Practice and Policy, eds. Peris-Ortiz, M. Garrigós-Simón, F.J., Gil Pechuán, I., 2014, Springer, Berlin, 41-49.

[17] Kolb, D.G., Shepherd, D.M. Concept mapping organizational cultures, in: Journal Management Inquiry, 1997,6 (4), 282-295.

[18] Collins, A.; Brown, J.-S., Holum, A. Cognitive Apprenticeship: Making Thinking Visible, in: American Educator, American Federation of Teachers, 1991, 6(11), 38-46.

[19] Roth, W. M., Roychoudhury, $\boldsymbol{A}$. The social construction of scientific concepts or the concept map as conscription device and tool for social thinking in high school science, in: Science education, 1992, 76(5), 531-57.

[20] Roth, W. M., Roychoudhury, A. The concept map as a tool for the collaborative construction of knowledge: A microanalysis of high school physics students, in: Journal of Research in Science Teaching, 1993, 30(5), $503-534$.

[21] Coffey, J. W., Hoffman, R. R., Cañas, A. J., Ford, K. M. A concept-map based knowledge modeling approach to expert knowledge sharing, in: Proceedings of IKS, Int. Conf. on Information and Knowledge Sharing, 2002, IASTED, 212-217.

[22] Dewey, J. The School and Society and The Child and the Curriculum, University of Chicago Press, Chicago (reprints from 1900 and 1902).

[23] Kinchin, I. M., Alias, M. Exploiting variations in concept map morphology as a lesson-planning tool for trainee teachers in higher education, in: Journal of In-service Education, 2005, 31(3), 569-592.

[24] Boland, R.J., Jr., Tenkasi, R.V. Perspective Making and Perspective Taking in Communities of Knowing, in: Organization Science, 1995, 6(4), 350-372.

[25] McAleese, $\boldsymbol{R}$. The knowledge arena as an extension to the concept map: Reflection in action, in: Interactive Learning Environments, 1998, 6(3), 251-272.

[26] Hughes, G., Hay, D. Use of concept mapping to integrate the different perspectives of designers and other stakeholders in the development of e-learning materials, in: British Journal of Educational Technology, 2001, $32(5), 557-569$. 
[27] Hwang, G. J., Shi, Y. R., Chu, H. C. A concept map approach to developing collaborative Mindtools for context-aware ubiquitous learning, in: British Journal of Educational Technology, 2011, 42(5), 778-789.

[28] Hwang, G. J., Kuo, F. R., Chen, N. S., Ho, H. J. Effects of an integrated concept mapping and web-based problem-solving approach on students' learning achievements, perceptions and cognitive loads, in: Computers \& Education, 2014, 71, 77-86.

[29] Kinchin, I. M., Cabot, L. B., Hay, D. B. Using concept mapping to locate the tacit dimension of clinical expertise: Towards a theoretical framework to support critical reflection on teaching, in: Learning in Health and Social Care, 2008, 7(2), 93-104.

[30] Fleischmann, A., Schmidt, W., Stary, C., Obermeier, S., Börger, E. Subject-oriented business process management. Springer, 2012, Heidelberg.

[31] Weichhart, G. Der Dalton im e-Learning: Transformation einer Reformpädagogik ins Web, 2014, Trauner, Linz

[32] Weske, M. Business Process Management. Concepts, Languages, Architectures, $2^{\text {nd }}$ ed., 2012, Springer, Heidelberg.

[33] Kinchin, I. M. Concept Mapping as a Learning Tool in Higher Education: A Critical Analysis of Recent Reviews, in: The Journal of Continuing Higher Education, 2014, 62(1), 39-49.

[34] Novak, J.D., Gowin, D.B. Learning how to learn, Cambridge University Press, 1984, NY.

[35] Trochim, W.M.K. An introduction to concept mapping for planning and evaluation, in: Evaluation Program Planning, 1989, 12 (1), 1-16.

[36] Strauss, $\boldsymbol{A}$. Work and the Division of Labor, in: The Sociological Quarterly, 1985, 26(1), 1-19.

[37] O'Donnell, A.M., Dansereau, D.F., Hall, R.H. Knowledge Maps as Scaffold for Cognitive Processing, Educational Psychology Review. 2002, 14(2), 71-86.

[38] Swan, J., Scarbrough, H., Newell, S. Why don't (or do) organizations learn from projects?, in: Management Learning, 2010, 41(3), 325-344.

[39] Toral, S.L., Martinez-Torres, M.R., Barrero, F., Gallardo, S., Duran, M.J. An electronic engineering curriculum design based on concept-mapping techniques, in: International Journal of Technology and Design Education, 2007, 17 (3), 341-356.

[40] Sandberg, J. How do we justify knowledge produced within interpretive approaches?, in: Organizational Research Methods, 2005, 8 (1), 41-68.

[41] Lee, Y., Nelson, D. W. Viewing or visualising - which concept map strategy works best on problem-solving performance?, in: British Journal of Educational Technology, 2005, 36(2), 193-203.

[42] Cañas, A. J., Hill, G., Carff, R., Suri, N., Lott, J., Gómez,C., Eskridge, T.C., Arroyo, M., Carvajal, R. CmapTools: A knowledge modeling and sharing environment, in: Concept maps: Theory, methodology, technology, Proceedings of the $1^{\text {st }}$ International Conference on Concept Mapping, 2004, 1, 125-133.

[43] Oppl, S., Stary, Ch. Tabletop concept mapping, in: Proceedings 3rd International Conference on Tangible and Embedded Interaction, 2009, ACM, 275-282.

[44] Oppl, S., Stary, $\boldsymbol{C}$. Effects of a Tabletop Interface on the Co-construction of Concept Maps. In Human-Computer Interaction, in: Proceedings INTERACT 2011, Springer, Berlin, 443-460.

[45] Rentsch, J. R., Mello, A. L., Delise, L. A. Collaboration and meaning analysis process in intense problem solving teams, in: Theoretical Issues in Ergonomics Science, 2010, 11(4), 287-303.

[46] Stary, $\boldsymbol{C h}$. Non-disruptive knowledge \& business processing in Knowledge Life Cycles - Aligning Value Network Analysis to process management, in: Journal of Knowledge Management, 2014, 18(4), 651-686.

[47] Haslhofer, B., Sanderson, R., Simon, R., van de Sompel, H. Open Annotations on Multimedia Web Resources, in: Multimedia Tools and Applications, 2012, 12, 33-39.

[48] Weichhart, G. Bridging the gap between qualitative, empirical work and software design, in: Proc. $5^{\text {th }}$ Int. Conf. on Concept Mapping, 2012, 51-54.

[49] Weichhart, G. S-BPM education on the Dalton Plan: an e-learning approach, in: Proceedings S-BPM ONE - Education and Industrial Developments, Springer, 2012, Berlin Heidelberg, CCIS 284, 181-193.

[50] Weichhart, G., Stary, Ch. Traceable Pedagogical Design Rationales for Personalized Learning Technologies - An Interoperable System-to-System Approach, in: Int. Journal of People Oriented Programming, 2015, in print.

[51] Dewey, $\boldsymbol{J}$. Progressive education and the science of education, Progressive Education Association, 1928, New York.

[52] Parkhurst, H., Bassett, R., Eades, J., Rennie, B. Education on the Dalton plan, 1924, Bell, London.

[53] Rye, J. A., Rubba, P. A. An exploration of the concept map as an interview tool to facilitate the externalization of students' understandings about global atmospheric change, in: Journal of Research in Science Teaching, 1998, 35(5), 521-546.

[54] Middleton, J., Gorard, St., Taylor, Ch., Banan-Ritland, B. The "Compleat" Design Experiment. From Soup to Nuts, in: Handbook of Design Research Methods in Education. Innovations in Science, Technology, Engineering 
and Mathematics Learning and Teaching, eds. Kelly, A.E., Lesh, R.A., Baek, J.Y., Routledge, 2008, New York, 21-46.

[55] Auinger, A., Auinger, F., Derndorfer, C., Hallewell, J., Stary, Ch. Content Production for e-Learning in Engineering, in: iJET, Int. Journal of Emerging Technologies in Learning, 2007, 2(2), http://www.i-jet.org.

[56] Zaharieva, M., Klas, W. MobiLearn: An Open Approach for Structuring Content for Mobile Learning Environments, in: Proceedings Web Information Systems, LNCS, Vol. 3307, 2004, Springer, Berlin, 114-124, DOI: $10.1007 / 978-3-540-30481-411$.

[57] Clark, D. Instructional systems design concept $\quad$ map, 2007, at http://www.nwlink.com/ donclark/hrd/ahold/isd.html.

[58] Meder, N. Didaktische Ontologien, in: Globalisierung und Wissensorganisation. Neue Aspekte für Wissen, Wissenschaft und Informationssysteme, eds: Ohly, H.P., Rahmstorf, H., Sigel, A., 2002, 401-416), Ergon, Würzburg.

[59] Meder, N. (Ed.) Web-Didaktik: Eine neue Didaktik webbasierten, vernetzten Lernens. W. Bertelsmann Verlag, Bielefeld. 2006.

[60] Schluep, S. Modularization and Structured Markup for Web-based Learning Content in an Academic Environment, Shaker, Aachen. 2005.

[61] Chen, $\boldsymbol{C}$. M. Ontology-based concept map for planning a personalised learning path, in: British Journal of Educational Technology, 2009, 40(6), 1028-1058.

[62] Tseng, S. S., Sue, P. C., Su, J. M., Weng, J. F., Tsai, W. N. A new approach for constructing the concept map, in: Computers \& Education, 2007, 49(3), 691-707.

[63] Leake, A. V. D. Jump-starting concept map construction with knowledge extracted from documents, in: Proceedings $2^{\text {nd }}$ International Conference on Concept Mapping (CMC), 2006, 296-303.

[64] Larranaga, M., Elorriaga, J.A., Arruarte, A. Semi-Automatic Generation of Didactic Resources from Existing Documents, in: Intelligent Tutoring Systems, eds. Woolf et al., Lecture Notes in Computer Science, 2008 , Vol. 5091, Springer, Berlin, 728-730, DOI: 10.1007/978-3-540-69132-7_91.

[65] Schulmeister, R. Grundlagen hypermedialer Lernsysteme. Theorie, Didaktik, Design, Addison-Wesley, Bonn. 1996.

[66] Schulmeister, R. Lernplattformen für das virtuelle Lernen. Evaluation und Didaktik, Oldenbourg, München. 2003.

[67] $\boldsymbol{A D L}$ Sharable Content Object Reference Model (SCORM), http://www.adlnet.org, 2012.

[68] Leidig, T. L3 - Towards an Open Learning Environment, in: ACM Journal of Educational Resources in Computing, 2001, 1 (1), article 5.

[69] Lazar, J. The World Wide Web, in: The Human-Computer Interaction Handbook: Fundamentals, Evolving Technologies and Emerging Applications, eds. J. Jacko, A. Sears, Mahaw, NJ: Lawrence Erlbaum, 2003, 714-730.

[70] Chase, W. G. Visual Information Processing, in: Handbook of Perception and Human Performance, Vol. II: Cognitive Processes and Performance, eds. K.R. Boff, L. Kaufman, J.P. Thomas, John Wiley, New York, 1986, 28-1 28-71.

[71] Rovine, M. J., Weisman, G. D. Sketch-map Variables as Predictors of Way-finding Performance, in: Journal of Environmental Psychology, 1989, 9, 217-232.

[72] Godwin, S., McAndrew, P., Santos, A. Behind the Scenes of OpenLearn: The Challenges of Researching the Provision of Open E-Learning Resources, in: The Electronic Journal of E-Learning, 2008, 6(2), 139-148, www.ejel.org.

[73] Tham, Ch.W., Werner, J.M. Designing and Evaluating E-Learning in Higher Education. A Review and Recommendations, in: Journal of Leadership and Educational Studies, 2005, 11(2), 15-25.

[74] Chen, N. S., Wei, C. W., Chen, H. J. Mining e-Learning domain concept map from academic articles, in: Computers \& Education, 2008, 50(3), 1009-1021.

[75] Sue, P. C., Weng, J. F., Su, J. M., Tseng, S. S. A new approach for constructing the concept map, in: Proceedings IEEE International Conference on Advanced Learning Technologies, 2004, 76-80.

[76] Sumner, T., Ahmad, F., Bhushan, S., Gu, Q., Molina, F., Willard, S., Wright, M., Davis, L., Janée, G. Linking learning goals and educational resources through interactive concept map visualizations, in: International Journal on Digital Libraries, 2005, 5(1), 18-24.

[77] Neubauer, M., Stary, Ch., Oppl, St. Polymorph Navigation Utilizing Domain-specific Metadata: Experienced Benefits for e-Learners, in: Proceedings ECCE'11, $29^{\text {th }}$ Annual European Conference on Cognitive Ergonomics, ACM, 2011, 45-52, DOI: 10.1145/2074712.2074722.

[78] Schmiech, M. Didaktische Ontologien zur Organisation digitaler Objekte in der Arbeit von Lehrkräften, PhD Thesis. 2006, Flensburg.

[79] Fürlinger, St., Auinger, A., Stary, Ch. Interactive Annotations in Web-based Learning Environments, in: Proceedings ICALT'04, $4^{\text {th }}$ International Conference on Advanced Learning Technologies, 2004, IEEE, 360-364. 
[80] Rudan, Sa., Rudan, Si. SocioTM - Relevancies, Collaboration and Socio-knowledge in Topic Maps, eds. Maicher, L., Garshol, L.M., TMRA 2008 (Topic Map Research and Application), 285-299, Leipzig.

[81] Farmer, R. A., Hughes, B. A Situated Learning Perspective on Learning Object Design, in: Proceedings of ICALT05, IEEE. 2005.

[82] Assareh, A., Hosseini Bidokht, M. Barriers to e-teaching and e-learning, in: Procedia Computer Science, 2011, 3, 791-795.

[83] Hung, J. Trends of e-learning research from 2000 to 2008: Use of text mining and bibliometrics, in: British Journal of Educational Technology, 2012, 43, 5-16.

[84] Yau, J., Lam, J., Cheung, K.S. A review of e-Learning Platforms in the Age of e-Learning 2.0, Hybrid Learning and Education, Lecture Notes in Computer Science, LNCS 5685, 2009, 208-217.

[85] Khalid, S.U., Basharat, A., Shahid, A.A., Hassan, S. An adaptive E-learning Framework to supporting new ways of teaching and learning, in: Proceedings Int. Conf. on Information and Communication Technologies, 2009, 300306.

[86] Alario-Hoyos, C., Bote-Lorenzo, M.L., Gómez-Sánchez, M.L., Asensio-Pérez,J.I., Vega-Gorgojo, G., RuizCalleja, A. GLUE!: An architecture for the integration of external tools in Virtual Learning Environments, Computer and Education, 2013, 60, 122-137.

[87] Zardas, G. The Importance of integrating Learning Theories and Pedagogical Principles in AHES (Adaptive Hypermedia Educational Systems), in: Proceedings Int. Conf. On Advanced Learning Technologies, ICALT'08, IEEE. 2008.

[88] Parkhurst, H. Education On The Dalton Plan, 1923, 2010, nabu Press.

[89] Tiropanis, Th., Millard, D., Davis, H.C. Guest Editorial: Special Section on Semantic Technologies for Learning and Teaching Support in Higher Education, in: IEEE Transactions on Learning Technologies, IEEE, 2012, 5(2), 102-103

\title{
ОНТОЛОГИИ ДЛЯ ОБРАЗОВАТЕЛЬНЫХ ПРОЕКТОВ, ОРИЕНТИРОВАННЫЕ НА ЗАИНТЕРЕСОВАННЫХ ЛИЦ
}

\author{
К. Стари ${ }^{1, \mathrm{a}}$, М. Нойбауэр ${ }^{1, \mathrm{~b}}$, Ст. Оппл ${ }^{1, \mathrm{c}}$, Г. Вейчарт ${ }^{2}$ \\ ${ }^{I}$ Кафедра информащионных бизнес систем и технической кибернетики университета Иоганна Кеплера, Линц, \\ Aвстрuя,www.ce.jku.at, ${ }^{a}$ Christian.Stary@jku.at, ${ }^{b}$ Matthias.Neubauer@jku.at, ${ }^{c}$ Stefan.Oppl@jku.at \\ ${ }^{2}$ Profactor GmbH, Шmейp, Aвстрия,www.profactor.at, Georg.Weichhart@profactor.at
}

\begin{abstract}
Аннотация
Электронное обучение и управление знаниями становятся всё более интерактивными и богатыми контентом. Они включают социальный, когнитивный и технологический аспекты. Концептуальные карты - эффективный способ создания и организации знаний для обмена контентом и инициации поведения в процессе обучения и развития. В силу того, что структура концептуальных карт проста и процедуры доступны для понимания, заинтересованные лица могут получать выгоду от описательных возможностей концептуальных карт. Они позволяют представлять не только релевантную информацию, но также раскрывать различные взгляды на элементы информации. Таким образом, возможна передача значимого контента и характеристик для взаимодействия. Мы демонстрируем неинвазивное применение концептуальных карт к проектированию сред обучения, ориентированных на пользователя. Подход охватывает вопросы от формирования облика образовательных проектов и разметки дидактического контента до целенаправленной навигации и отслеживаемых проектных пространств. Мы используем метаданные для кодирования образовательных устремлений при поддержке обучения. Их обработка может быть совмещена с существующими функциями систем поддержки обучения, включая социальные сети. Как показали наши исследования, за счёт понимания процесса разработки такого приложения как процесса обучения, концептуальное моделирование обеспечивает системное понимание при контекстно-зависимом проектировании.
\end{abstract}

Ключевье слова: онтологический инжиниринг, конщептуальная карта, электронное обучение, генерация знаний, представление знаний, карта тем, обмен знаниями, прогрессивное образование, самостоятельное изучение материала, проектирование, ориентированное на пользователя, проектное пространство, распределенные системь. 


\section{Сведения об авторах}

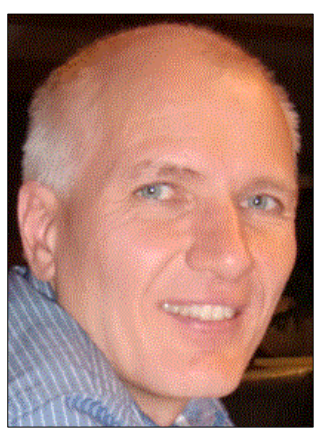

Кристиан Стари (1960 г.р.) - руководитель кафедры информационных бизнес систем и технической кибернетики и Центра компетенций управления знаниями университета Иоганна Кеплера в г. Линц. После завершения диссертации по направлению «проектирование интерактивных систем» в Венском технологическом университете несколько лет работал в качестве приглашенного профессора в ряде университетов США и Европы. Является членом Института управления инновационными процессами (www.i2pm.net), поддерживающего самодостаточные инновации в эко системах. Президент Международного Совета по управлению знаниями (www.ickm.net) и Австрийского общества организационного обучения (www.sol-austria.at). Как главный исследователь международных научно-исследовательских проектов, К. Стари управляет созданием и обменом междисциплинарными знаниями, в то время как его команда разрабатывает системы поддержки обучения, ориентированные на заинтересованных лиц. Недавно Кристиан Стари был назначен главным редактором Международного журнала науки о взаимодействиях издательства Шпрингер.

Professor Christian Stary (b. 1960) is currently head of the Department of Business Information Systems Communications Engineering, and head of the JKU Knowledge Management Competence Center at the Johannes Kepler University of Linz. After finishing his PhD studies at Vienna University of Technology on Interactive Systems Engineering he has held several visiting professor positions in the US and Europe. He is engaged in international research and development communities such as the Institute of Innovative Process Management (www.i2pm.net) to foster sustainable innovations of eco systems. He is acting president of the International Council of Knowledge Management (www.ickm.net) and the Society of Organizational Learning Austria (www.sol-austria.at). As principal investigator of international research and development projects he manages transdisciplinary knowledge creation and transfer with his team targeting stakeholder-centered learning support and distributed systems development. Recently, Christian Stary has been appointed editor-in-chief of the International Journal of Interaction Science published by Springer.

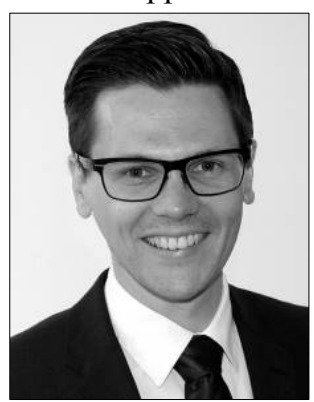

Матиас Нойбауэр (1982 г.р.) - научный сотрудник и руководитель проектов на кафедре информационных бизнес систем и технической кибернетики университета Иоганна Кеплера (JKU) в г. Линц. Матиас принимал участие в различных исследовательских проектах кафедры, таких как TwinTide (http://www.twintide.org/), IANES (http://ianes.eu/) или Comprehand. После защиты диссертации в JKU он начал работать в качестве координатора проектов в рамках EU FP7 Project "Subject-Orientation for People-Centred Production" (www.so-pc-pro.eu). Сфера его научных интересов охватывает вопросы проектирования ICT для промышленности с ориентацией на пользователя. Особое внимание уделяется совершенствованию рабочего места человеко-центрической рабочей среды в контексте фабрик будущего.

Dr. Matthias Neubauer (b 1982) is researcher and project coordinator at the Department of Business Information Systems - Communications Engineering of the Johannes Kepler University Linz (JKU). Matthias contributed to various international research projects at the department like TwinTide (http://www.twintide.org/), IANES (http://ianes.eu/) or Comprehand. After finishing his PhD at JKU, he started to work as project coordinator for the EU FP7 Project "SubjectOrientation for People-Centred Production" (www.so-pc-pro.eu). His current research interest is the human-centred design of ICT support for industry. Particular emphasis is placed on human-centred workplace improvement in the context of factories of the future.

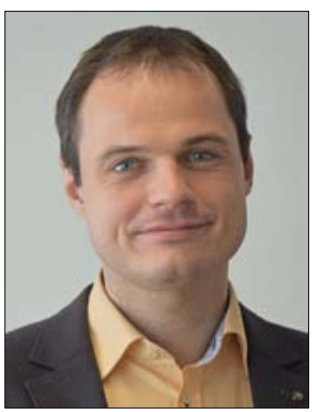

Стефан Оппл (1980 г.р ) - доцент кафедры информационных бизнес систем и технической кибернетики в университете Иогана Кеплера г. Линц, Австрия. Имеет опыт работы в компьютерных науках (MSc), в области управления знаниями (MBA), защитил докторскую диссертацию по компьютерным наукам в Техническом университете Вены в 2010 году. С 2003 работает научным сотрудником в университете Иоганна Кеплера $(\mathrm{JKU})$ в г. Линц. В своих ранних работах он изучал контекстно-зависимые системы поддержки групп и системы поддержки мобильного обучения. С 2006 года разрабатывает средства для поддержки совместной работы и экстернализации знаний, а также согласования процессов в организационной среде. Стефан Оппл участвовал в нескольких европейских проектах и в настоящее время является координатором и ведущим научным сотрудником проекта EU FP7 Project "Subject-Orientation for People-Centred Production", координировал проект трансфера инноваций Леонардо да Винчи FARAW (www.faraw.eu) и программой SURGEOM (www.surgeom.eu).

Stefan Oppl (b. 1980) in an assistant professor at the Department of Business Information Systems - Communications Engineering at the Johannes Kepler University of Linz, Austria. He has a background in computer science (MSc) and applied knowledge management (MBA) completed his $\mathrm{PhD}$ in computer science at the Technical University of 
Vienna in 2010. Since 2003, he is working as a researcher at the Kepler University of Linz. In his early research, he has been working in the area of context-aware group support and mobile learning support systems. Since 2006, he is developing means to support collaborative work and knowledge externalization and alignment processes in organizational settings. He has been involved in several national and EU-founded research project and currently is the coordinator and lead scientist of the EU FP7-founded research project IANES (www.ianes.eu). He has also coordinated the Leonardoda-Vinci Transfer-of-Innovation project FARAW (www.faraw.eu) and the Erasmus Intensive Programme SURGEOM (www.surgeom.eu).

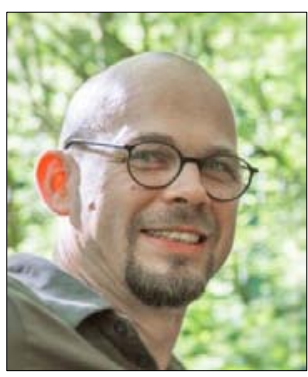

Георг Вейчарm (1972 г.р.) - научный сотрудник Profactor Gmbh, Австрия. В проекте, результаты которого изложены в статье, он выполнял роль научного сотрудника и лектора на кафедре информационных бизнес систем и технической кибернетики в университете Иогана Кеплера (JKU) г. Линц, Австрия. Он выступил как опытный научный сотрудник в проекте IANES IAPP и Metasonic GmbH, работая над интероперабельностью и «субъектоориентированным управлением бизнес-процессами». До этого он обучался в университете Ланда, университете Вены и защитил диссертацию в JKU г. Линц. Помимо академических должностей, он также работал в качестве старшего инженерапрограммиста и руководителя проектами в частных компаниях. Также он участвовал в качестве старшего научного сотрудника и архитектора программного обеспечения во многих европейских исследовательских проектах. Его текущее исследование связано с разработкой ICT для сложных адаптивных организационных систем. Особое внимание уделяет электронному обучению и функциональной совместимости. Георг Вейчарт - вице-председатель технического комитета IFAC 5.3: «Корпоративная интеграция и сети», а также член совета IFIP Work Group 5.8: «Корпоративная совместимость».

Dr. Georg Weichhart (b 1972) is key researcher at Profactor Gmbh in Austria. During the work presented in this article, he has been researcher and lecturer at the Business Information Systems - Communications Engineering Department of the Johannes Kepler University Linz (JKU). He has been applied through the IANES IAPP project as experienced researcher at Metasonic GmbH working on interoperability and "Subject-Oriented Business Process Management". Before this, he has been studying at Lund University, Vienna University and received his PhD from JKU Linz. Besides academic positions he worked as senior software engineer and project manager at private companies. In addition to this, he has been participating as senior researcher and software architect in numerous European research projects. His current research interest is ICT support for complex adaptive organisational systems. Particular emphasis is placed on e-learning and interoperability. Georg Weichhart is Industry Vice-Chair of the IFAC Technical Committee 5.3: "Enterprise Integration and Networking". He is also member of the board of the IFIP Work Group 5.8: "Enterprise Interoperability". 